\title{
Article
}

\section{Design and Realization of a Hybrid Excited Flux Switching Vernier Machine for Renewable Energy Conversion}

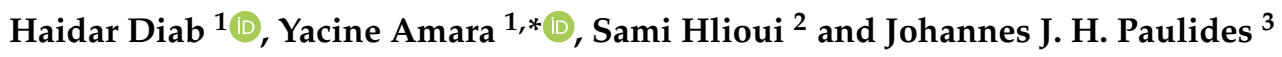 \\ 1 GREAH, Université Le Havre Normandie, 76600 Le Havre, France; haidar.diab@univ-lehavre.fr \\ 2 SATIE, Conservatoire National des Arts et Métiers, 75003 Paris, France; sami.hlioui@cnam.fr \\ 3 Advanced Electromagnetics B.V., Industrieweg 78, 5145 PW Waalwijk, The Netherlands; johan@ae-grp.nl \\ * Correspondence: yacine.amara@univ-lehavre.fr
}

check for

updates

Citation: Diab, H.; Amara, Y.; Hlioui,

S.; Paulides, J.J.H. Design and

Realization of a Hybrid Excited Flux

Switching Vernier Machine for Renewable Energy Conversion.

Energies 2021, 14, 6060. https://

doi.org/10.3390/en14196060

Academic Editor:

Audrius Bagdanavicius

Received: 29 July 2021

Accepted: 18 September 2021

Published: 23 September 2021

Publisher's Note: MDPI stays neutral with regard to jurisdictional claims in published maps and institutional affiliations.

Copyright: (c) 2021 by the authors. Licensee MDPI, Basel, Switzerland. This article is an open access article distributed under the terms and conditions of the Creative Commons Attribution (CC BY) license (https:// creativecommons.org/licenses/by/ $4.0 /)$.
Abstract: This paper presents the design of a hybrid excited flux switching Vernier machine. This machine is designed to serve in renewable energy conversion applications, such as a wind turbine generator, or tidal turbine generator. After introducing this original structure, a design based on finite element models is conducted. The specifications correspond to relatively low power direct drive wind or tidal turbine applications. The rated power is set to $10 \mathrm{~kW}$, with a rated speed of $300 \mathrm{rpm}$. Mainly the electromagnetic design is presented. Aspects related to the realization of a prototype are also presented, and an experimental study is included.

Keywords: hybrid excitation; Vernier effect; flux switching; renewable energy; wind turbine; tidal turbine

\section{Introduction}

Problems linked to the use of fossil fuels are pushing our societies to find viable and sustainable alternatives for their replacement. The use of nuclear energy, even if it emits less polluting greenhouse gases, does not cause fewer problems. Indeed, radioactive wastes, the products of nuclear power plants, have a lifespan that exceeds several generations, the management of which is problematic.

In this context, renewable energies constitute a viable and lasting solution, since their potential is enormous, and they do not emit greenhouse gases. The French Environment and Energy Management Agency (Ademe), aims that France should produce, by 2050, 100\% of its electrical energy from renewable energies at acceptable economic costs [1]. Among the different renewable energy sources, marine renewable energies (MRE), i.e., offshore wind, wave energy (wave power) and tidal turbines, are those that offer the least intermittency problems [2]. Tidal turbines, for example, harness the energy of oceanic marine currents which are continuous over time, or that of tidal currents which are relatively predictable [2]. France has a strong development potential for MRE, given the natural assets of its territory (11 million $\mathrm{km}^{2}$ of water under its jurisdiction) [3]. This known resource, estimated between 2 and $3 \mathrm{GW}$, is mainly concentrated off the coasts of Normandy, Brittany and Pays de la Loire [3].

In this paper, the electromagnetic design of a hybrid excited flux switching synchronous machine with a Vernier effect is presented [4]. Its structure is inspired by works carried out on flux switching machines which include hybrid excitation [5-7], and those including the Vernier effect [8,9]. A similar structure was the subject of a Chinese patent [4]. Such structures can be qualified as original, and are not well studied. Furthermore, the structure studied in this research also includes damper windings used for the mitigation of voltage induced in the wound field excitation windings [10-14]. This structure can be used as a generator (alternator) in low-speed applications such as direct drive wind turbines or tidal turbines. After a presentation of the structure of this machine, sizing based on finite element method models is proposed. The sizing is carried out on the basis of specifications 
for a direct drive wind turbine of $10 \mathrm{~kW}$, rotating at a speed of $300 \mathrm{rpm}$ [15]. Some elements concerning the realization of a prototype are also presented.

Vernier effect machines $[16,17]$ are well suited to low speed, high torque applications, which is characteristic of renewable energy applications. Furthermore, flux-switching machines have structures where all the sources of magnetic fields can be placed in a fixed part. This allows efficient cooling, and therefore better performance stability. In addition, the use of double excitation reduces the need for high-performance rare earth magnets, the extraction of which is extremely polluting, while allowing better controllability of performance. It is also possible to replace high-performance magnets with ceramic magnets (ferrite magnets).

The use of hybrid-excited machines in renewable energy applications, and more specifically wind power, has been the subject of several studies over the past two decades [18-27]. In reference [21], the author shows that double-excited machines can be an economically attractive solution compared to conventional machines with permanent magnets based on rare earths.

\section{Structure and Electromagnetic Design of Studied Machine}

Table 1 lists some elements of the specifications on which the design of the studied structure is based. These are specifications used at GREAH laboratory as a reference for comparing several prototypes $[15,28]$. Figure 1 shows the structure of the studied machine. It is a flux-switched hybrid-excited synchronous machine, also including the Vernier effect [4-9]. While sharing similarities with the structure presented in [4], the number of stator modules and rotor teeth are different.

Table 1. Prototype's general characteristics.

\begin{tabular}{lc}
\hline \multicolumn{1}{c}{ Quantity } & Value \\
\hline Nominal power $(\mathrm{kW})$ & 10 \\
Nominal rotation speed $(\mathrm{rpm})$ & 300 \\
External radius $(\mathrm{mm})$ & 200 \\
Active length $(\mathrm{mm})$ & 120 \\
Air-gap thickness $(\mathrm{mm})$ & 1 \\
PM characteristics $\left(\mathrm{B}_{\mathrm{r}}(\mathrm{T}), \mu_{\mathrm{r}}\right)$ & $1.25,1$ \\
Number of turns of armature windings & 9 \\
Number of turns of excitation coil & 31 \\
\hline
\end{tabular}

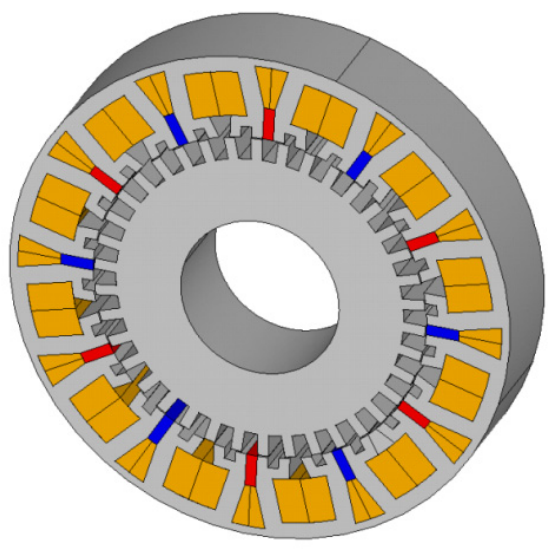

(a)

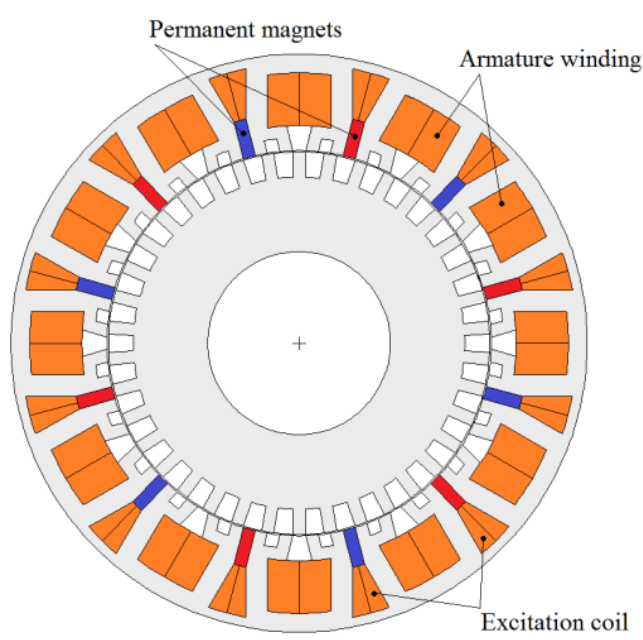

(b)

Figure 1. Studied machine structure: (a) 3D view; (b) face view showing the magnetic field sources. 
The dimensions were obtained by applying homothetic rules from the cited works. Figure 2 shows detailed dimensions of the stator and rotor. It is a three-phase machine, having 12 stator modules, each including a permanent magnet, a slot for the armature windings, and a slot for the excitation winding. The rotor is completely passive, and has 38 teeth. By having an even number of rotor teeth, the unbalanced magnetic force is null if the rotor is well centered.

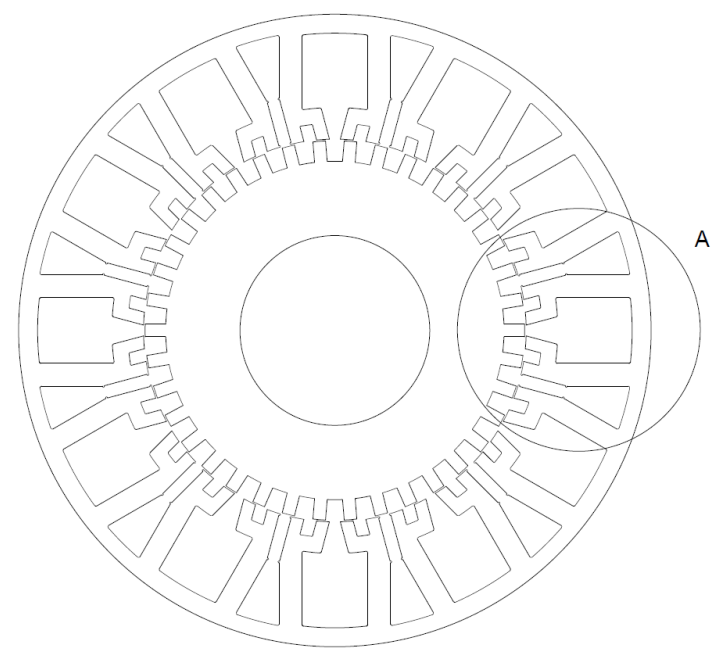

(a)

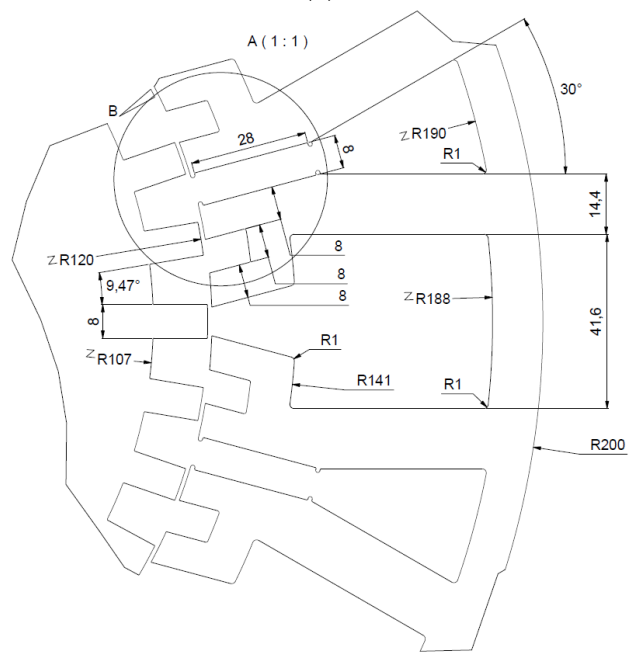

(b)

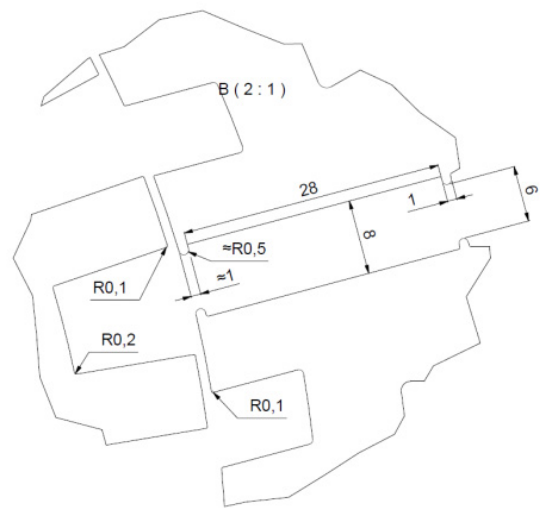

(c)

Figure 2. Dimensions of the studied machine (Courtesy of AE-Group, The Netherlands): (a) 2D axial cut; (b) zoom on zone A; (c) zoom on zone B. 
The numbers of turns for the two types of windings, armature and excitation, are given in Table 1. The number of turns of the armature windings is calculated to be consistent with the voltage levels of GREAH laboratory installations (three-phase $230 \mathrm{~V} / 400 \mathrm{~V}$ grid). In order to efficiently remove losses from the stator, water cooling is adopted. The water jacket is made of nonmagnetic material to avoid further short-circuiting the permanent magnets flux and therefore reduce the armature magnetic flux linkage.

Figure 3 shows the armature windings and the excitation winding distributions. The armature windings are composed of concentrated coils. This helps to reduce the end windings' lengths. There is no overlap between the windings of the three phases. However, there is an overlap between the armature windings and the field excitation winding.

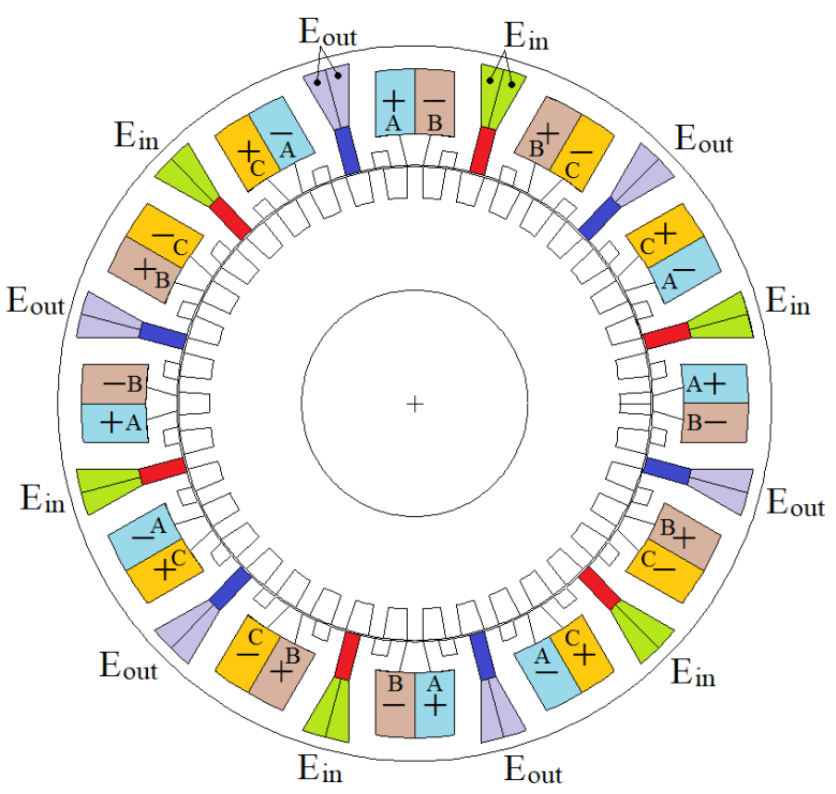

Figure 3. Armature and excitation field windings distributions.

One of the issues related to the presence of excitation windings in flux switching machines is the induced voltage that may be experienced by these windings [10-14]. To address this issue, a solution developed at SATIE laboratory was adopted [29]. It consists of adding damping windings (DW) along the two other windings sets, i.e., armature and wound field excitation windings. This solution consists in having, along with the excitation coils, coils wound the same way as the excitation coils, and short circuited. Doing so, the current induced in the short-circuited coil helps reduce the pulsating flux responsible for the induced voltage pulsation. More details are provided in the sections dedicated to the prototype construction and experimental study.

\section{Performance Analysis}

The 2D finite element method (FEM) was used for the study of machine performance. Figure 4 shows the meshed studied domain. The ratio between the air-gap radius and the active length is consistent with the use of a 2D FEM approach.

Taking into account the geometrical and physical symmetries, it is sufficient to model half of the machine (Figure $4 \mathrm{a}$ ). Figure $4 \mathrm{~b}$ shows a zoom in on the region of the air gap, which should be given special attention. The elements size discretization imposed to the points and the lines belonging to the air-gap region was set to $1 / 6 \mathrm{~mm}$. This discretization was imposed to have a sufficient number of elements to get useful information when computing the cogging torque, or the torque ripples. Indeed, the period of cogging torque is equal to

$$
\alpha_{\text {mec. }}=360^{\circ} / \operatorname{LCM}(12,38) \approx 1.579^{\circ},
$$

which corresponds to a distance of approximately $3.31 \mathrm{~mm}$ at the rotor outer radius. 


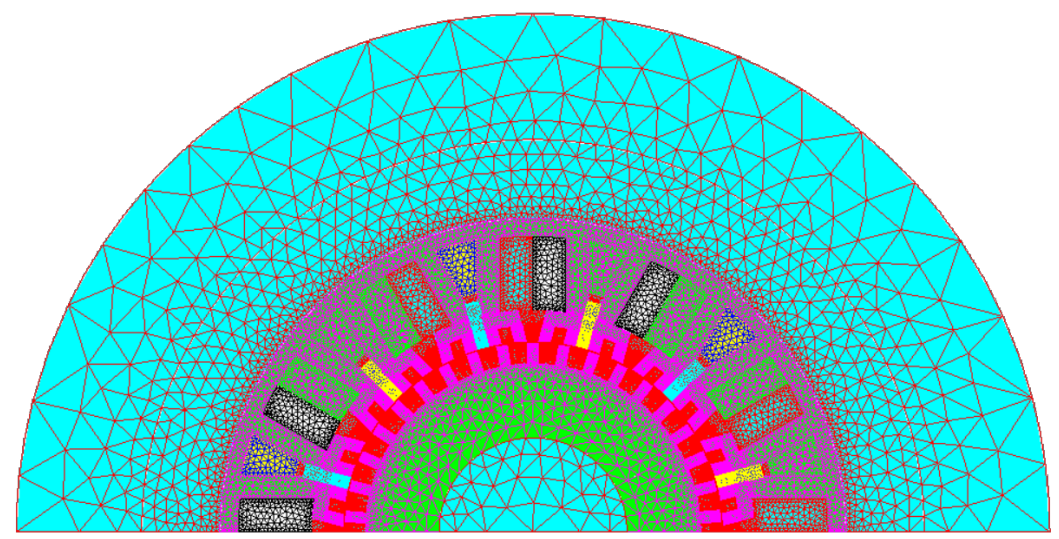

(a)

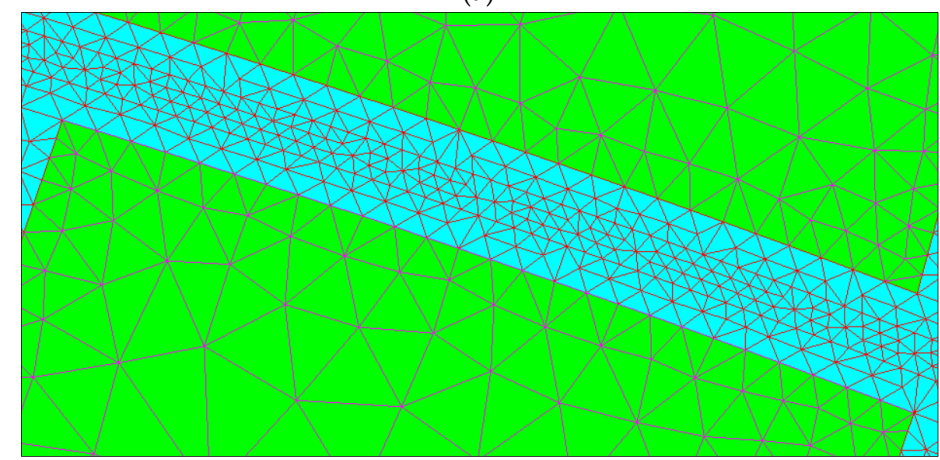

(b)

Figure 4. 2D FE model: (a) 2D Mesh of studied domain; (b) zoom on air-gap region.

The machine's external environment was modeled using a device called an "infinite box" [30]. The mesh consists of 69,626 surface elements of the second order, with 139,495 nodes. Details about the mesh are given in Figure 5. The calculations are mainly carried out in magneto-static mode with the vector potential as unknown. For the computation of permanent magnets eddy current loss, the magneto-dynamic mode was adopted. Magnetic saturation was considered in this study. Figure 6 shows the $\mathrm{B}(\mathrm{H})$ curve of the material used for the ferromagnetic parts. Circuit coupling was adopted to model the armature windings and the excitation winding, and was also adopted when computing the permanent magnets eddy current loss. This coupling was configured to ensure that a null net total current flows in each permanent-magnet surface [31].

Figure 7 compares the EMFs of the structure in its pure wound-field (WF) version (the permanent magnets are replaced by the air) and hybrid-excited (HE) version for $\mathrm{J}_{\mathrm{exc}}=5 \mathrm{~A} / \mathrm{mm}^{2}$ (current density of the excitation current). The hybrid excitation allows an increase in excitation flux linkage of $35 \%$ compared to the wound-field excitation version.

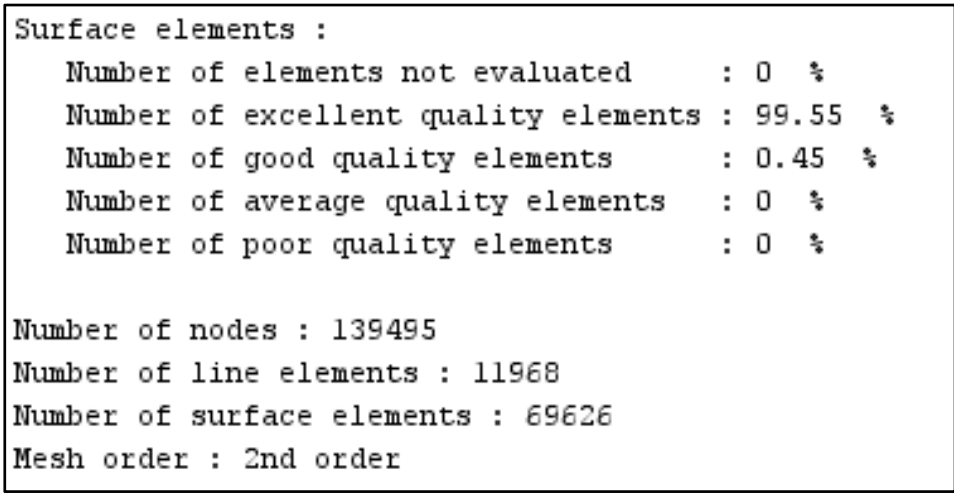

Figure 5. Mesh evaluation in Flux2D. 


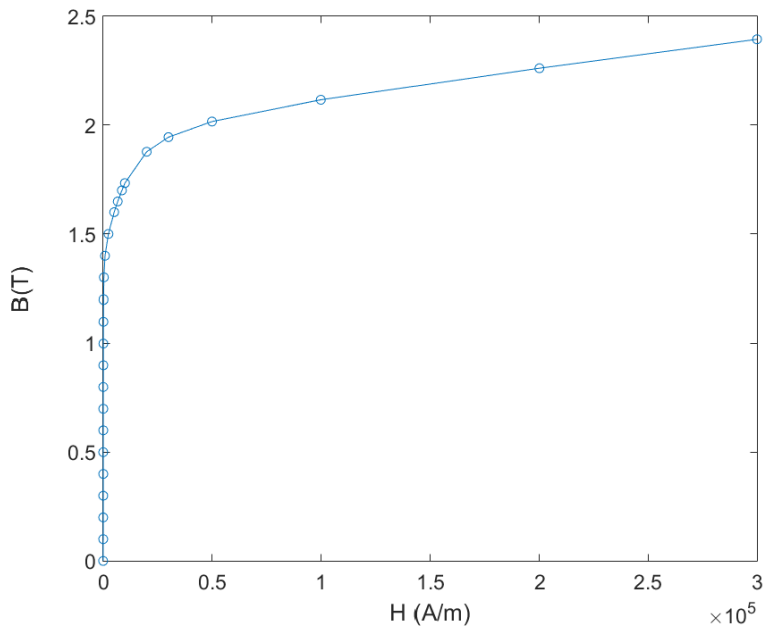

Figure 6. $\mathrm{B}(\mathrm{H})$ curve of the material used for the ferromagnetic parts (M330-35A).

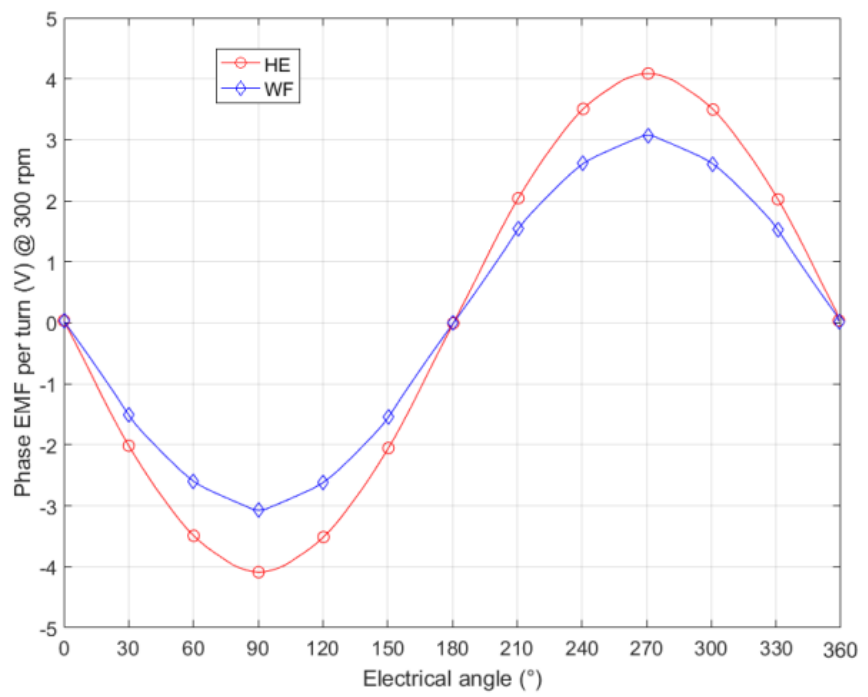

(a)

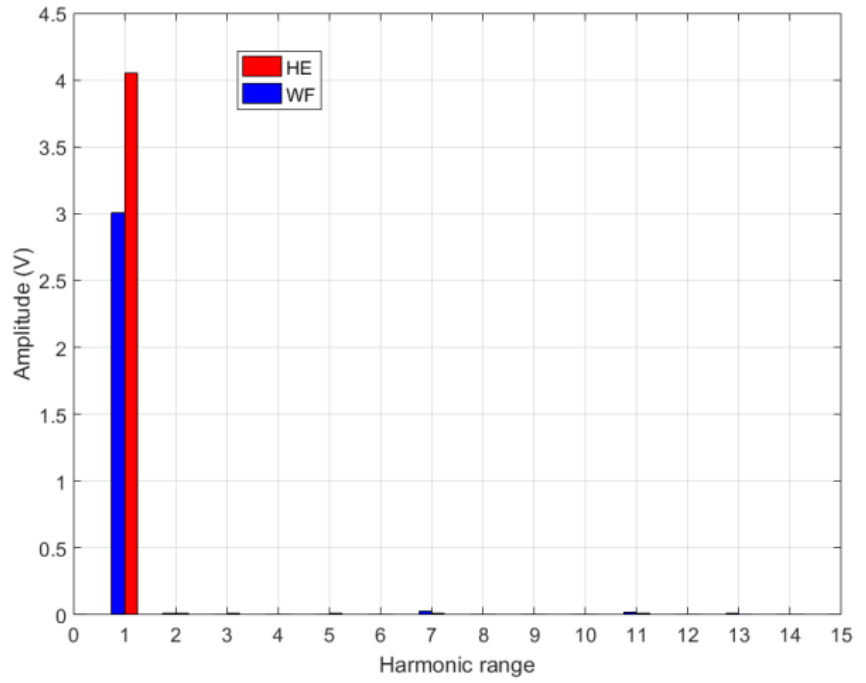

(b)

Figure 7. EMF waveforms comparison for WF and HE versions: (a) EMF waveforms; (b) harmonic contents. 
The period, in mechanical angles, of the FEMs is equal to:

$$
\theta_{\text {mec. }}=360^{\circ} / 38 \approx 9.4737^{\circ} \text {, }
$$

where the number 38 corresponding to the number of rotor teeth and constitutes the number of pairs of poles $(p=38)$. The waveforms of FEMs are very close to a sinusoid, with a fairly low harmonic content.

Figure 8 shows the EMF waveforms for different values of the excitation current and compares their harmonic contents. As before, the EMF waveforms are very close to sinusoid. It can be seen that adding excitation flux is more efficient than reducing it. Figure 9 shows the cogging torque waveforms of different values of excitation current.

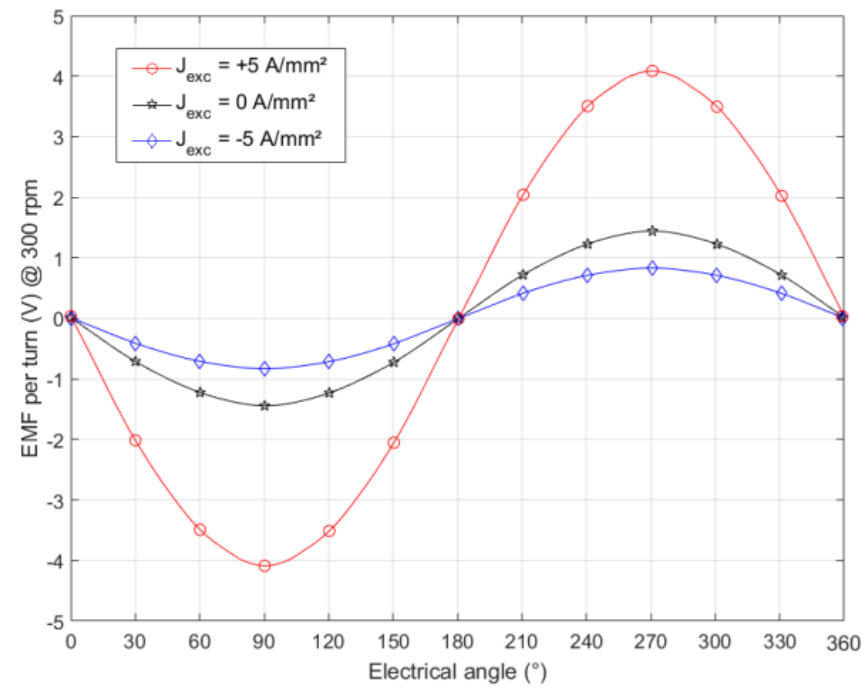

(a)

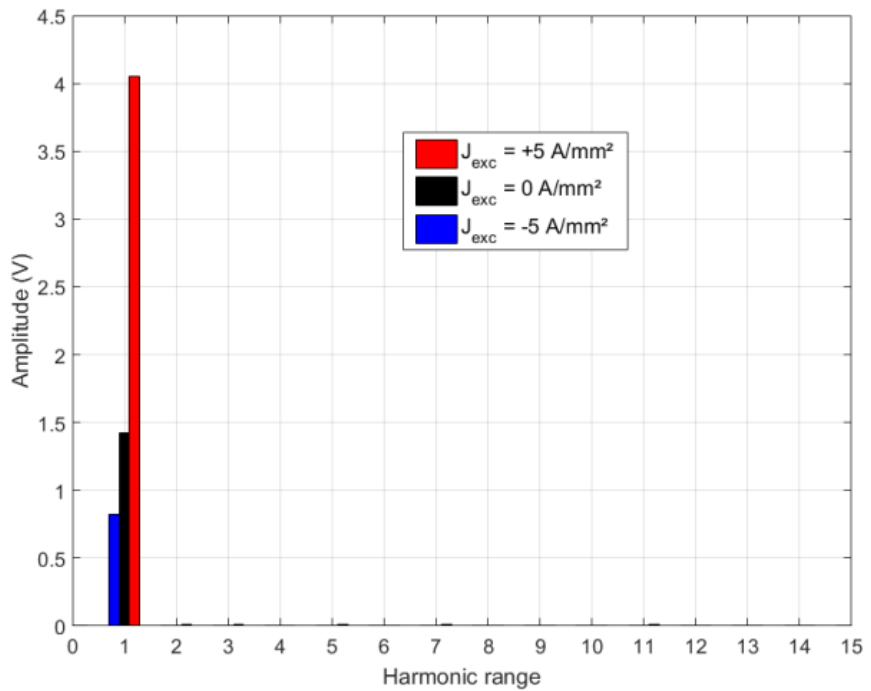

(b)

Figure 8. EMF waveforms comparison for different excitation current values: (a) EMF waveforms; (b) harmonic contents. 


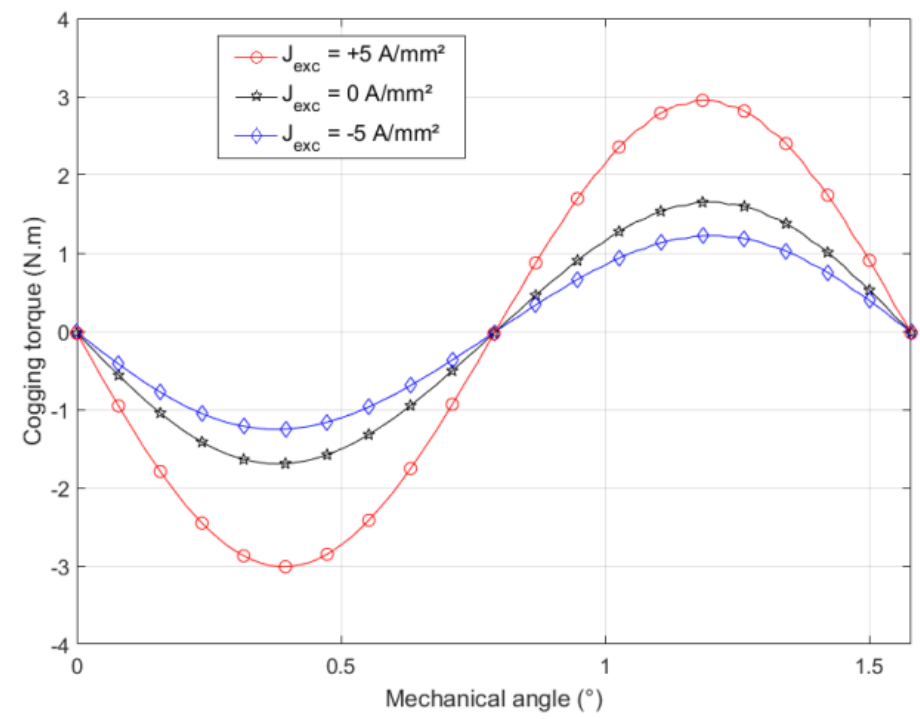

Figure 9. Cogging torque waveforms for different excitation current values.

Figure 10 shows the variation of the load torque for two values of the excitation current density $\mathrm{J}_{\mathrm{exc}}=0$ and $5 \mathrm{~A} / \mathrm{mm}^{2}$. The RMS value of armature current density was set to $5 \mathrm{~A} / \mathrm{mm}^{2}$. The load torque was estimated for an armature current in phase with the EMF in each phase $\left(\psi=0^{\circ}\right)$. The fill factor for the armature windings and the excitation coils was identical, and equal to $40 \%$. Figure 11 shows variation of the load torque with the angle $\psi$. These computations were done for an RMS value of armature current density $\mathrm{J}_{\mathrm{Arm}}=5 \mathrm{~A} / \mathrm{mm}^{2}$, and $\mathrm{J}_{\mathrm{exc}}=5 \mathrm{~A} / \mathrm{mm}^{2}$. The machine behaves as a nonsalient synchronous machine. Figure 12a shows the torque waveforms for different values of the RMS value of armature current density $\mathrm{J}_{\mathrm{Arm}}, \mathrm{f}$ for $\mathrm{J}_{\mathrm{exc}}=5 \mathrm{~A} / \mathrm{mm}^{2}$. The armature current is in phase with the EMF in each phase $\left(\psi=0^{\circ}\right)$, for these computations. Figure $12 \mathrm{~b}$ shows the variation of the mean value of the torque with the armature current density RMS value.

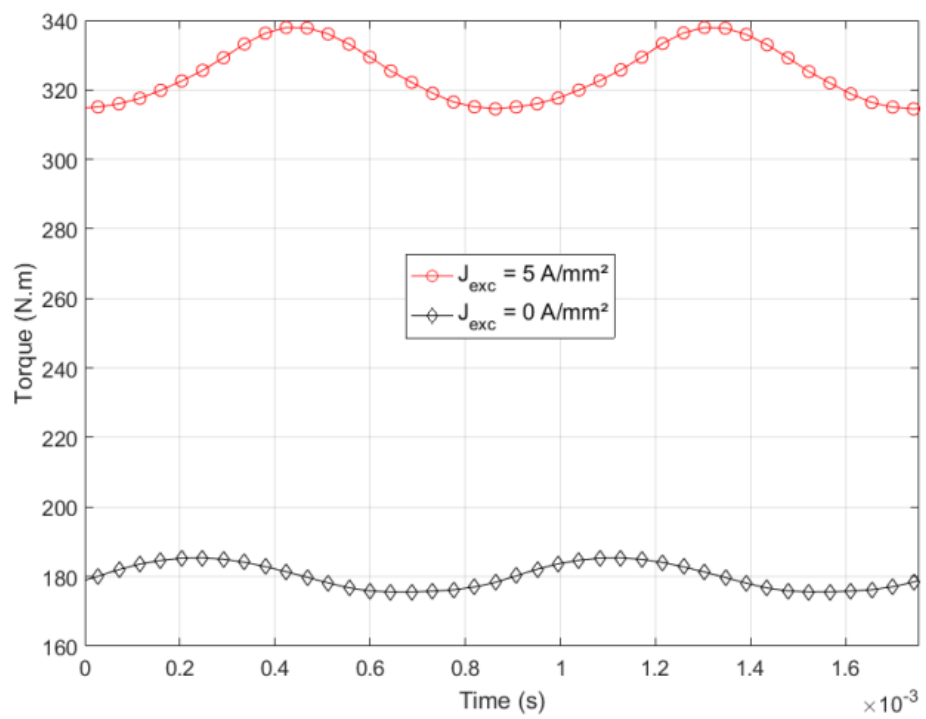

Figure 10. Load torque waveforms for $\mathrm{J}_{\mathrm{Arm}}=5 \mathrm{~A} / \mathrm{mm}^{2}$ (phase armature current in phase with the phase EMF). 


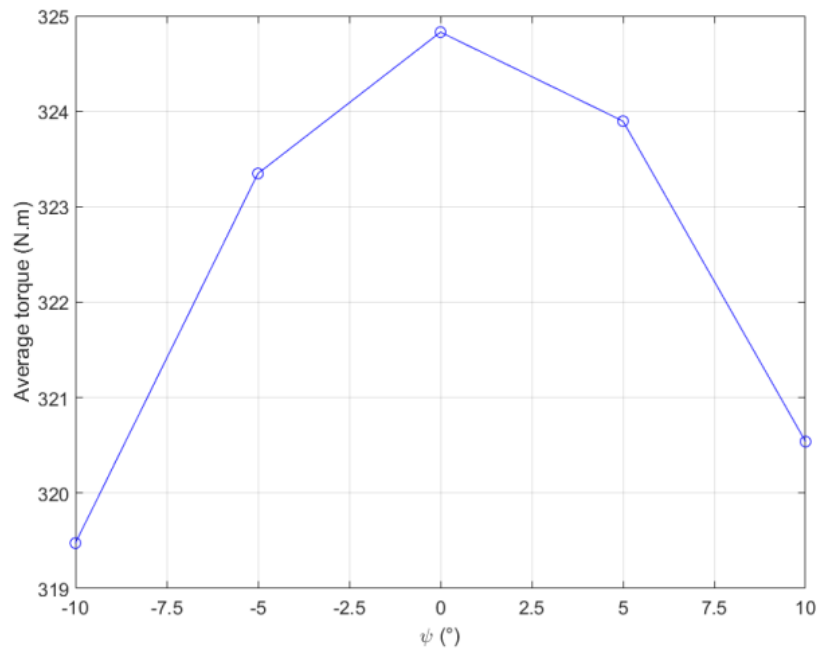

Figure 11. Average load torque variation with angle $\psi$.

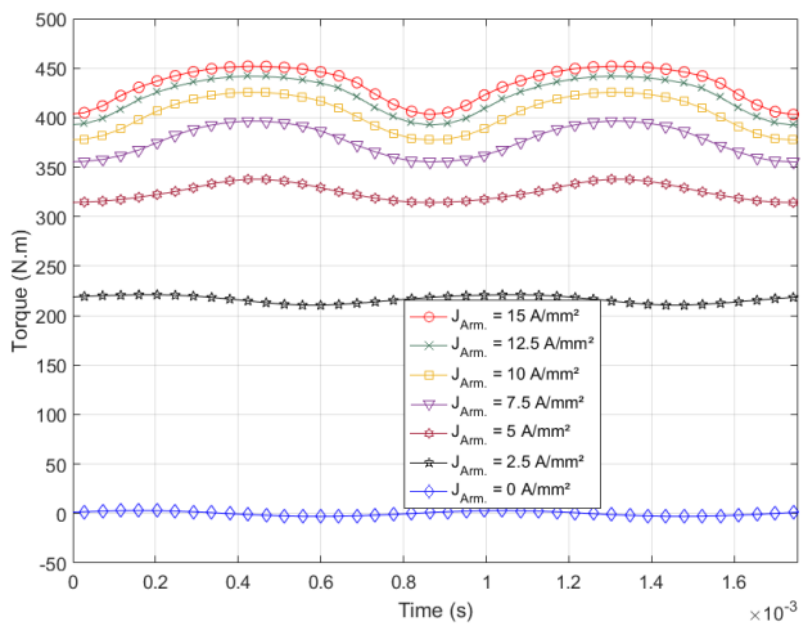

(a)

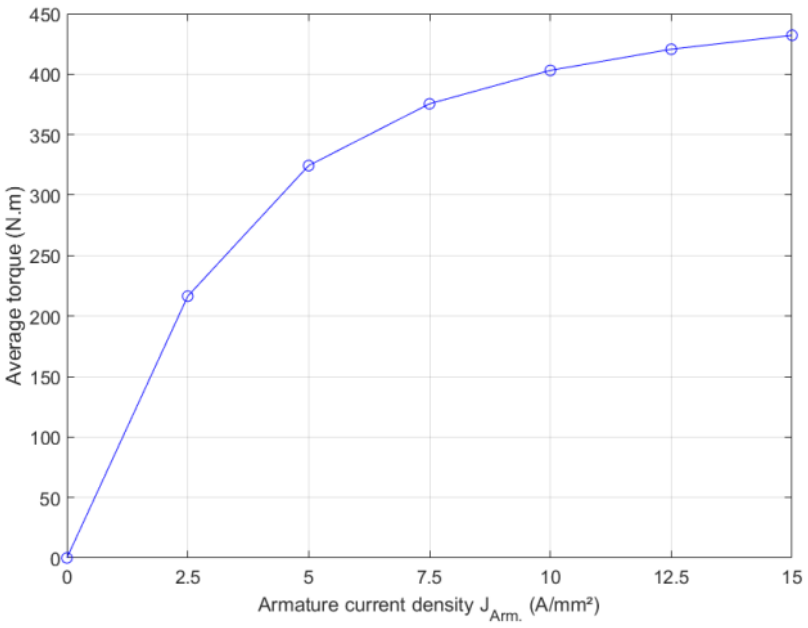

(b)

Figure 12. Load torque variations with different values of $\mathrm{J}_{\mathrm{Arm}}$ : (a) load torque waveforms; (b) average torque variation. 
The nominal torque for a nominal power of $10 \mathrm{~kW}$ at a nominal rotation speed of $300 \mathrm{rpm}$ was equal to $\approx 318$ N.m. This value was reached for an armature current density RMS value of nearly $5 \mathrm{~A} / \mathrm{mm}^{2}$ when $\mathrm{J}_{\text {exc }}=5 \mathrm{~A} / \mathrm{mm}^{2}$.

Figure 13 shows the torque ripple ratio for the different values of the armature current corresponding to the torque waveforms shown in Figure 12a. This ratio is computed as

$$
T R_{r}=\frac{T_{\text {max }}-T_{\text {min }}}{T_{\text {average }}}
$$

The torque ripple ratio was less than $12 \%$ for the analyzed waveforms. For $\mathrm{J}_{\text {exc }}=5 \mathrm{~A} / \mathrm{mm}^{2}$ and $\mathrm{J}_{\mathrm{Arm}}=5 \mathrm{~A} / \mathrm{mm}^{2}$, this ratio was equal to $7.3 \%$. It is possible to reduce it by optimizing the dimensions of the machine. It would also be possible to look for the best combination $\left(\mathrm{J}_{\mathrm{exc}}, \mathrm{J}_{\text {Arm. }}\right)$ to reduce it while keeping the torque at its nominal value.

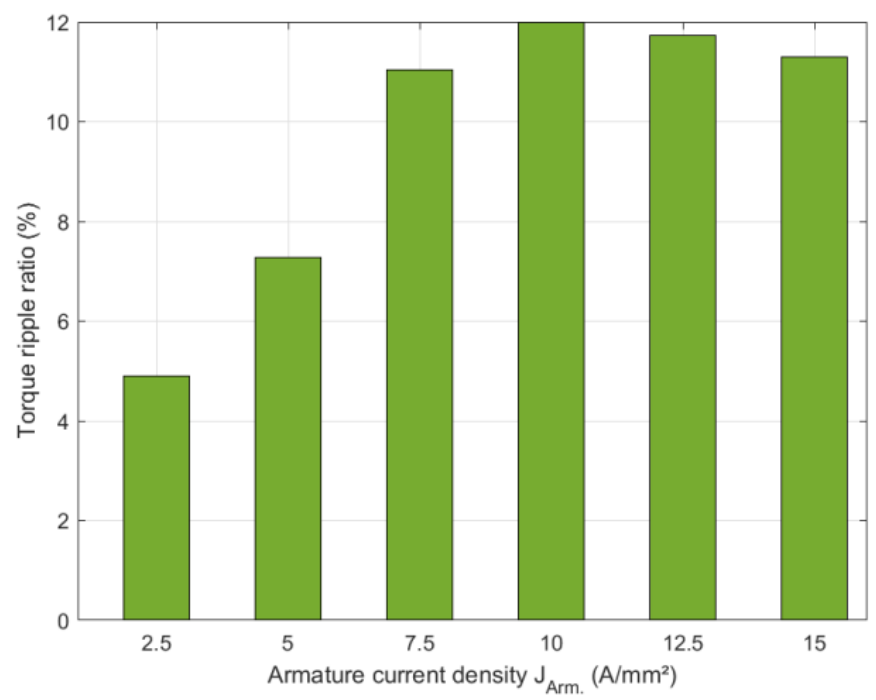

Figure 13. Load torque variations with different values of $\mathrm{J}_{\mathrm{Arm}}$ : (a) load torque waveforms; (b) average torque variation.

Figure 14 shows the magnetic state of the structure for a given position for $\mathrm{J}_{\mathrm{exc}}=$ $5 \mathrm{~A} / \mathrm{mm}^{2}$ and $\mathrm{J}_{\text {Arm. }}=5 \mathrm{~A} / \mathrm{mm}^{2}$; the armature current being in phase with the EMF in each phase. As can be seen, some areas of the machine are well saturated, and it is in the stator and rotor teeth that this is more particularly pronounced.

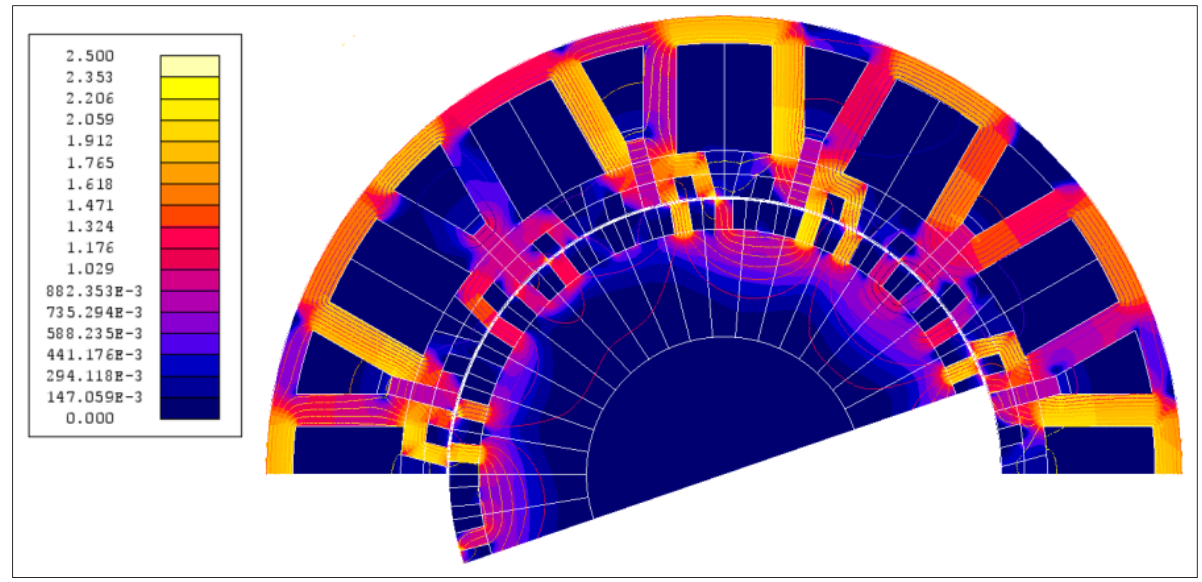

Figure 14. Magnetic flux density distribution (the scale is in Tesla) and flux lines. 
Figure 15 shows the phase voltage (Figure 15a) and the armature current (Figure 15b) for a given phase when $\mathrm{J}_{\mathrm{exc}}=5 \mathrm{~A} / \mathrm{mm}^{2}$ and $\mathrm{J}_{\mathrm{Arm}}=5 \mathrm{~A} / \mathrm{mm}^{2}$, the armature current being in phase with the EMF in each phase $\left(\psi=0^{\circ}\right)$.

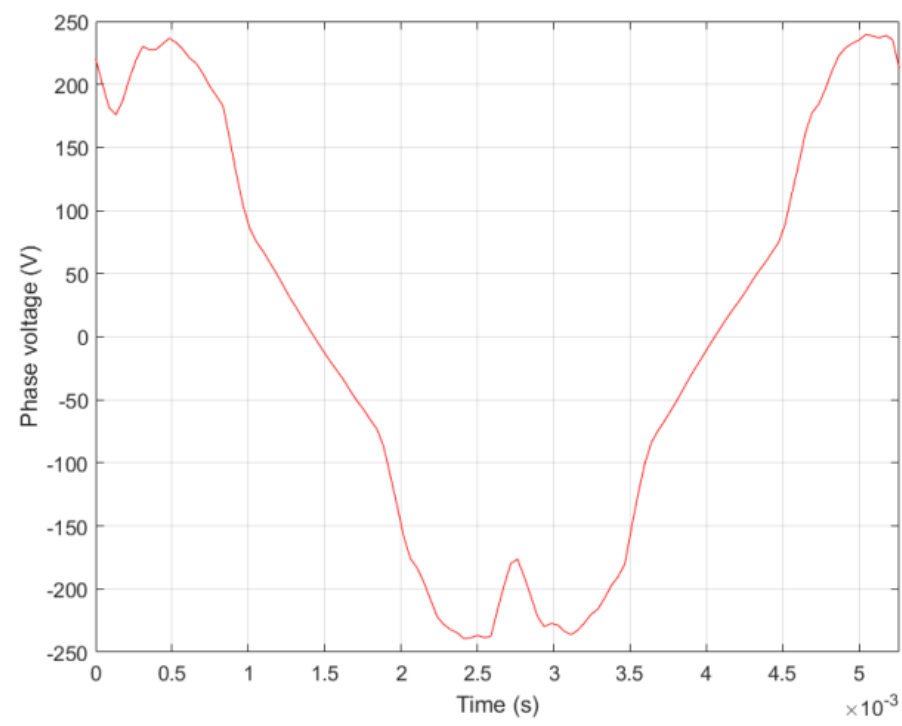

(a)

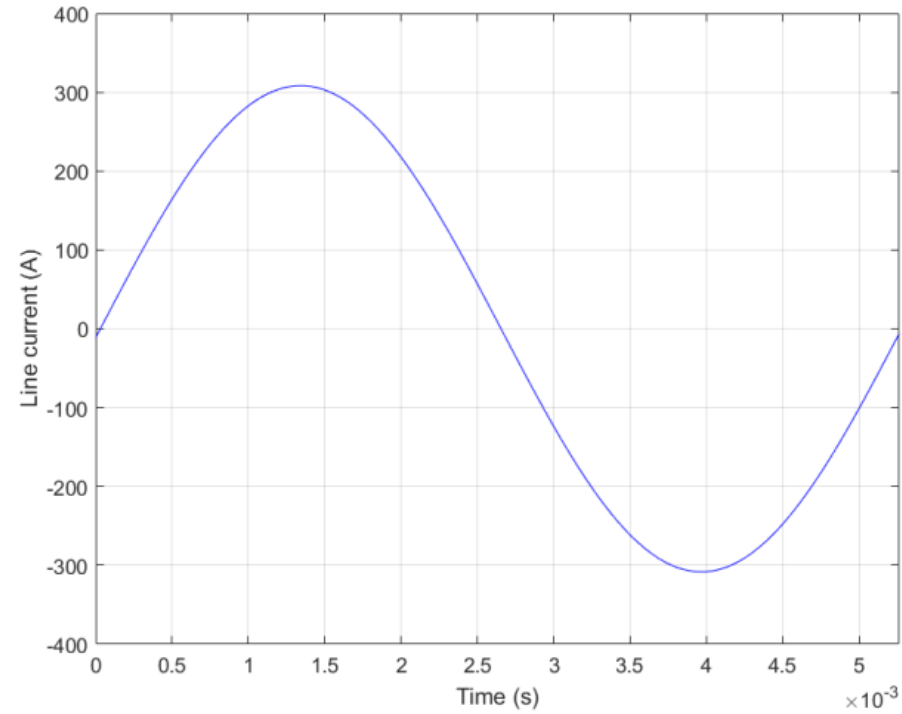

(b)

Figure 15. Phase voltage and armature current of a given phase: (a) phase voltage; (b) armature current.

It can be seen from the curves in Figure 15 that the power factor for this operation is relatively low ( $\mathrm{FP} \approx 0.147$ ). This is a characteristic of Vernier machines. It should be noticed that such low values have been reported by the authors of reference [6] for a hybrid excited flux switching machine not including the Vernier effect.

Figure 16 shows the harmonic content of the phase voltage (Figure 15a). The magnetic armature reaction is very important as compared to the excitation flux linkage, and its harmonic content is relatively rich. 


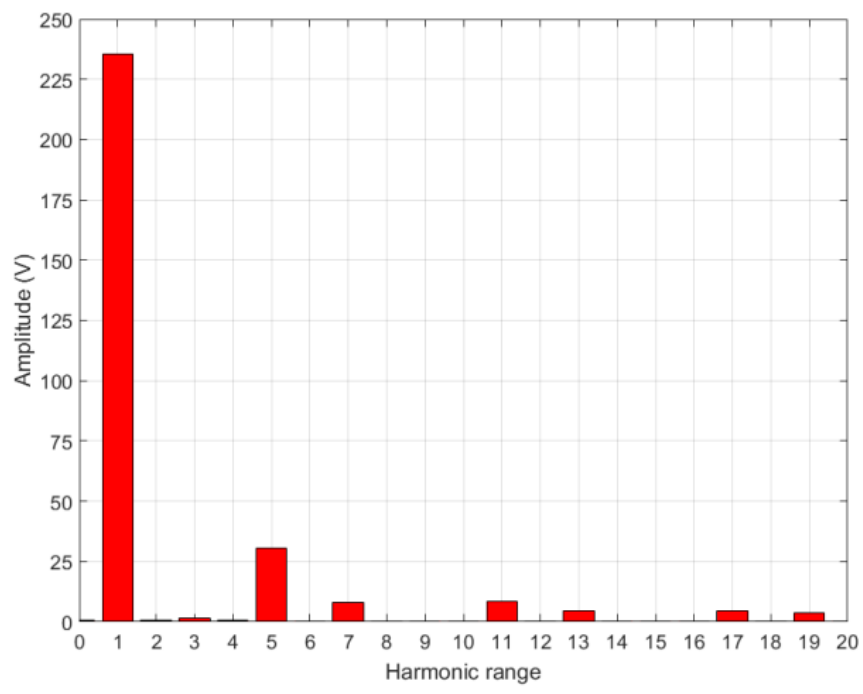

Figure 16. Harmonic content of the phase voltage.

Considering the low value of the power factor for this operating point, an alternative combination $\left(\mathrm{J}_{\mathrm{exc}}, \mathrm{J}_{\mathrm{Arm}}\right.$. $)$ was sought making it possible to respond to the nominal torque while improving the PF. Figure 17 shows the torque for $\mathrm{J}_{\mathrm{exc}}=10 \mathrm{~A} / \mathrm{mm}^{2}$ and $\mathrm{J}_{\mathrm{Arm}}=2.75 \mathrm{~A} / \mathrm{mm}^{2}$, the armature current being in phase with the EMF in each phase. This allows the magnetic armature reaction to be reduced, thus increasing the PF. The power factor FP for this operation was 0.254 .

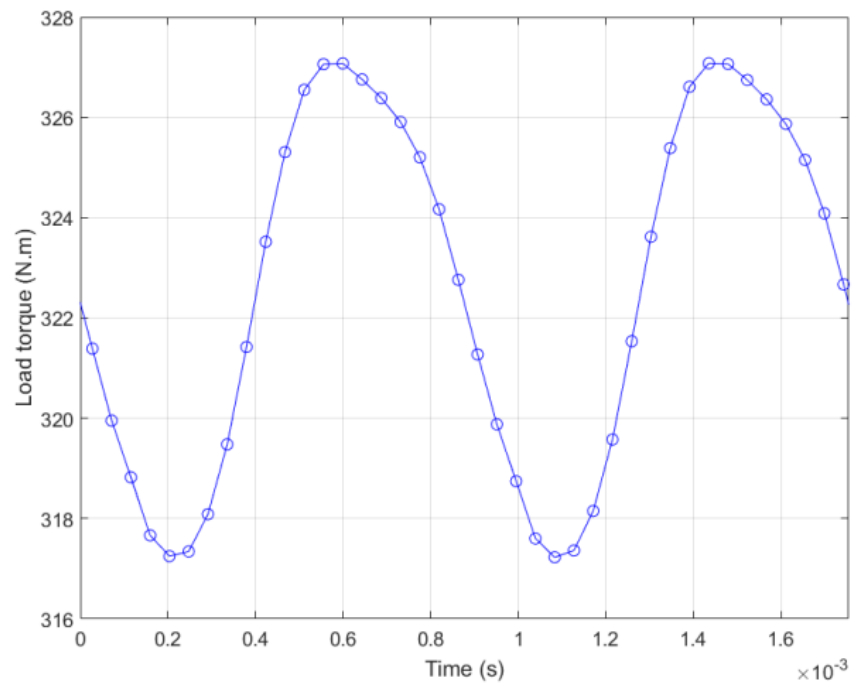

Figure 17. Load torque for $\mathrm{J}_{\mathrm{exc}}=10 \mathrm{~A} / \mathrm{mm}^{2}, \mathrm{~J}_{\mathrm{Arm}}=2.75 \mathrm{~A} / \mathrm{mm}^{2}$ and $\psi=0^{\circ}$.

Table 2 shows the loss balance for the two studied operations, for which the armature current is in phase with the EMF in each phase $\left(\psi=0^{\circ}\right)$ : Operation $1(\mathrm{~F} 1)\left(\mathrm{J}_{\mathrm{exc}}=5 \mathrm{~A} / \mathrm{mm}^{2}\right.$, $\left.\mathrm{J}_{\text {Arm. }}=5 \mathrm{~A} / \mathrm{mm}^{2}\right)$, Operation $2(\mathrm{~F} 2)\left(\mathrm{J}_{\text {exc }}=10 \mathrm{~A} / \mathrm{mm}^{2}, \mathrm{~J}_{\text {Arm. }}=2.75 \mathrm{~A} / \mathrm{mm}^{2}\right)$. Joule losses were estimated without taking the end-windings into account. Iron losses were estimated by the "Loss Surface" method available in Flux2D software [32].

Eddy current losses in permanent magnets are estimated considering that they are not segmented. Their segmentation in the radial and axial directions allows a significant reduction of these losses [33,34]. The significant difference in these losses for the two operations is related to the state of magnetic saturation, which is more heterogeneously distributed in the areas near the permanent magnets in the case of the first operation (F1). It 
should be noted that the iron losses in the rotor were respectively $114.62 \mathrm{~W}$ and $89.72 \mathrm{~W}$ for the two operations F1 and F2, respectively. The main iron losses component corresponded to the stator iron losses.

Table 2. Losses balance.

\begin{tabular}{lcc}
\hline \multicolumn{1}{c}{ Operation } & F1 & F2 \\
\hline Armature windings Joule loss $(\mathrm{W})$ & 480 & 145 \\
Excitation coil Joule loss $(\mathrm{W})$ & 165 & 659 \\
Iron loss $(\mathrm{W})$ & 843 & 664 \\
PM eddy current loss $(\mathrm{W})$ & 1261 & 41 \\
Total loss $\left(P_{\text {Loss }}\right)(\mathrm{W}) /$ Efficiency $\eta(\%)$ & $2749 / 73$ & $1509 / 85$ \\
\hline
\end{tabular}

The efficiency $\eta$ was estimated considering that the machine was operating in generator mode (alternator) using following formula

$$
\eta=\frac{T \cdot \Omega-P_{\text {Loss }}}{T \cdot \Omega}
$$

with $(T \cdot \Omega)$ is the provided mechanical power and $P_{\text {Loss }}$ the total loss.

It is important to retain from this performance analysis study, the additional degree of freedom offered by the use of hybrid excitation. The hybrid excitation allows controlling the air-gap magnetic field, and the selection of an adequate $\left(\mathrm{J}_{\mathrm{exc}}, \mathrm{J}_{\mathrm{Arm}}\right.$. $)$ combination to improve the efficiency and/or the power factor.

\section{Prototype Construction}

Figure 18 shows two CAD views of the prototype and its test bench. The test bench includes, in addition to the prototype, a drive or load machine with its power electronics [35]. The drive or load machine is an asynchronous machine associated with a mechanical gearbox for adjusting the rotation speed. This machine operates at higher speeds compared to the prototype.

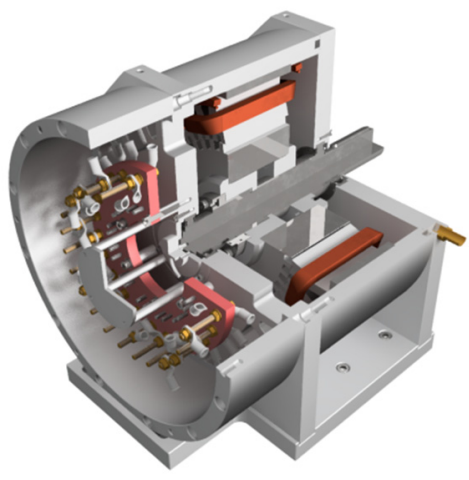

(a)

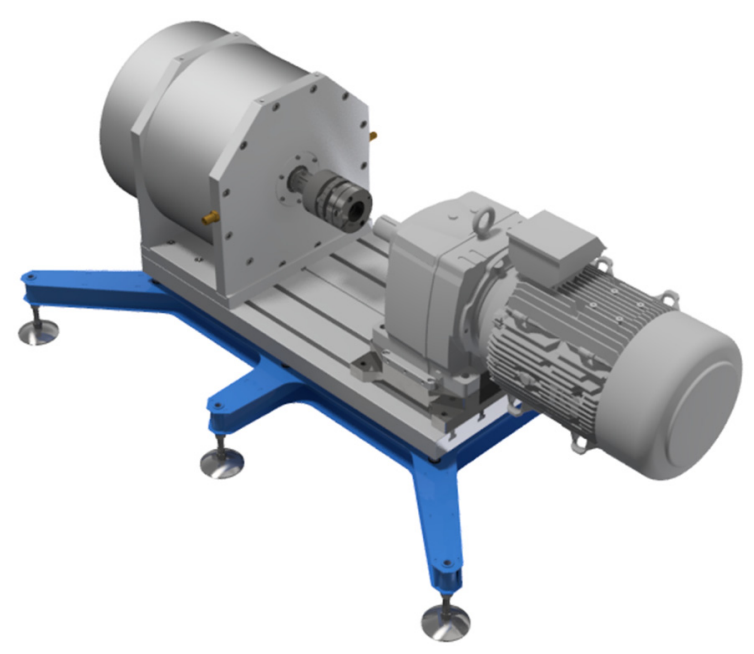

(b)

Figure 18. CAD views of the realized prototype (Courtesy of AE-Group, The Netherlands): (a) 3D cutaway view of the prototype; (b) prototype test bench.

As our laboratory floor could not support a load greater than $500 \mathrm{~kg} / \mathrm{m}^{2}$, the bench included a base specifically designed to widen its seat in order to reduce the load per square meter. 
Figure 19 illustrates the stator construction. Figure 19a shows the lamination sheets stack used for the construction of the stator. Figure $19 b, c$ shows the laminations stack installed in the EDM machine (wire cutting), during and after cutting of the stator. Figure $19 \mathrm{~d}$ shows the final stator laminated core.

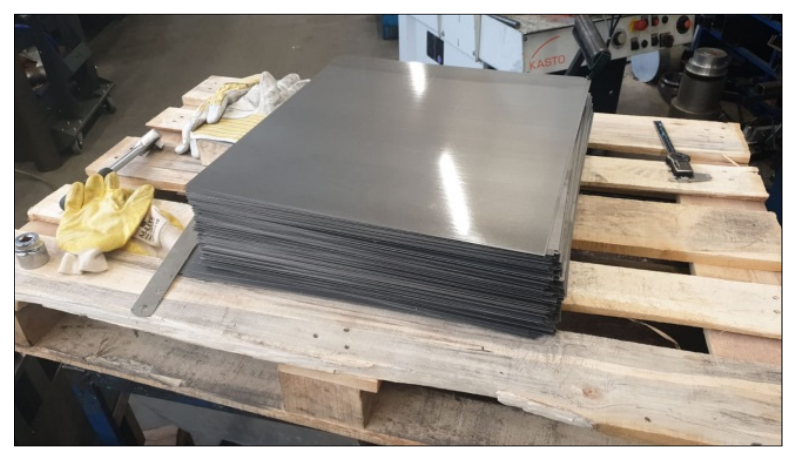

(a)

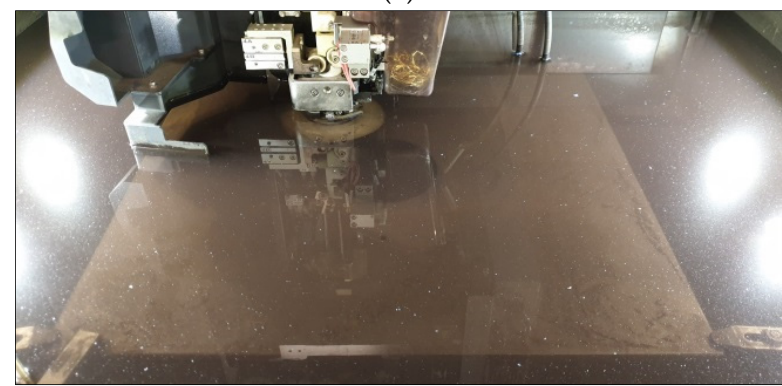

(b)

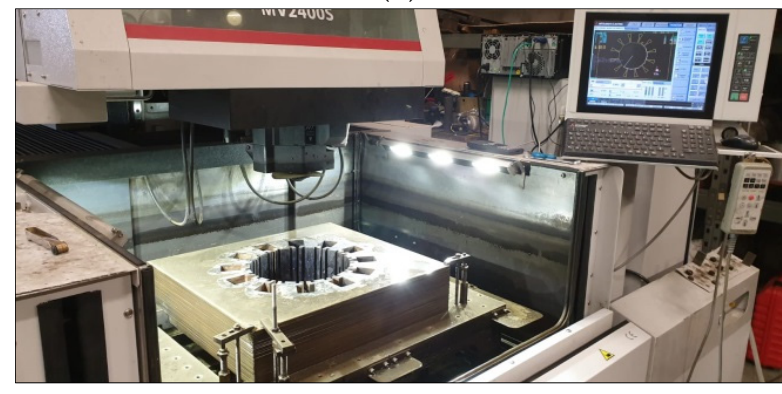

(c)

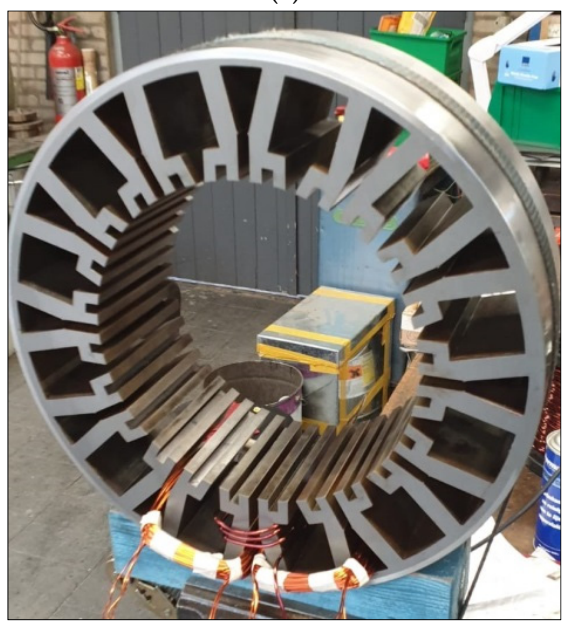

(d)

Figure 19. Stator construction (Courtesy of AE-Group, The Netherlands): (a) laminations sheets stack; (b) laminations stack during machining; (c) laminations stack after machining; (d) final stator laminated core. 
Figure 20 shows the jig constructed to produce the armature coils. Figure 21 shows the construction of the base specifically designed to support the prototype test bench. A torque meter is inserted between the two machines (Figure 18b) [36]. An estimate of the mass of the prototype, from the CAD software, indicated a mass of $285 \mathrm{~kg}$ for the active parts. Taking into account the load limit that can be supported by the soil of the GREAH laboratory $\left(<500 \mathrm{~kg} / \mathrm{m}^{2}\right)$, the base was designed to widen the base of the experimental bench (Figures $18 \mathrm{~b}$ and 21).

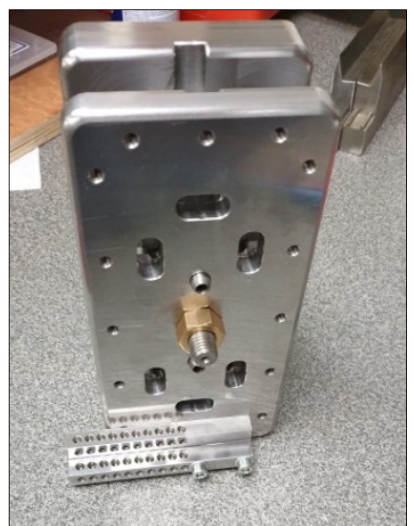

(a)

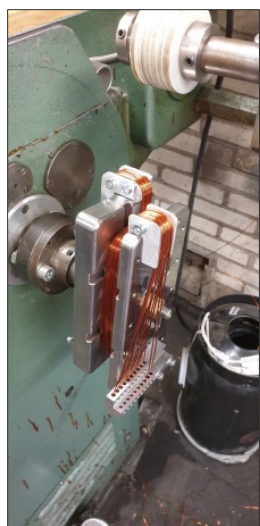

(b)

Figure 20. Jig for production of the armature windings (Courtesy of AE-Group, The Netherlands): (a) jig; (b) production of an armature coil using the jig.

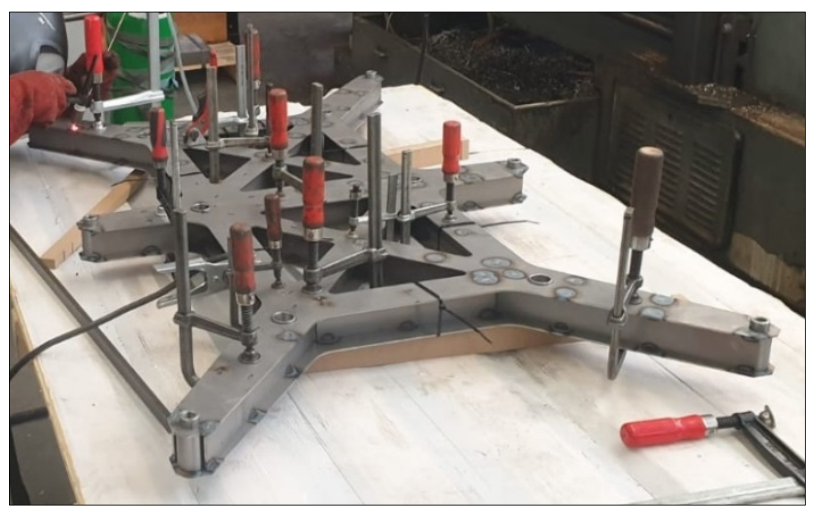

Figure 21. Production of the test bench base (Courtesy of AE-Group, The Netherlands).

Figure 22 shows technical drawings of the water-cooling system specifically designed for the prototype. It consists of a water jacket which surrounds the stator. A closed loop system is provided for the water supply to this system. This water cooling allows better performance stability. It also allows boosting the performance of the prototype without deterioration risk. The prototype is also equipped with a number of thermocouples distributed in several regions of the stator (armature windings, excitation winding, and permanent magnets). The temperature measurements help to assess the efficiency of the cooling system and diagnose the thermal state of the prototype. They also allow development of a fine thermal model.

Figure 23 shows the prototype back side with stator windings and coil connections clearly visible. A zoom-in on this figure shows the thermocouples terminals. 

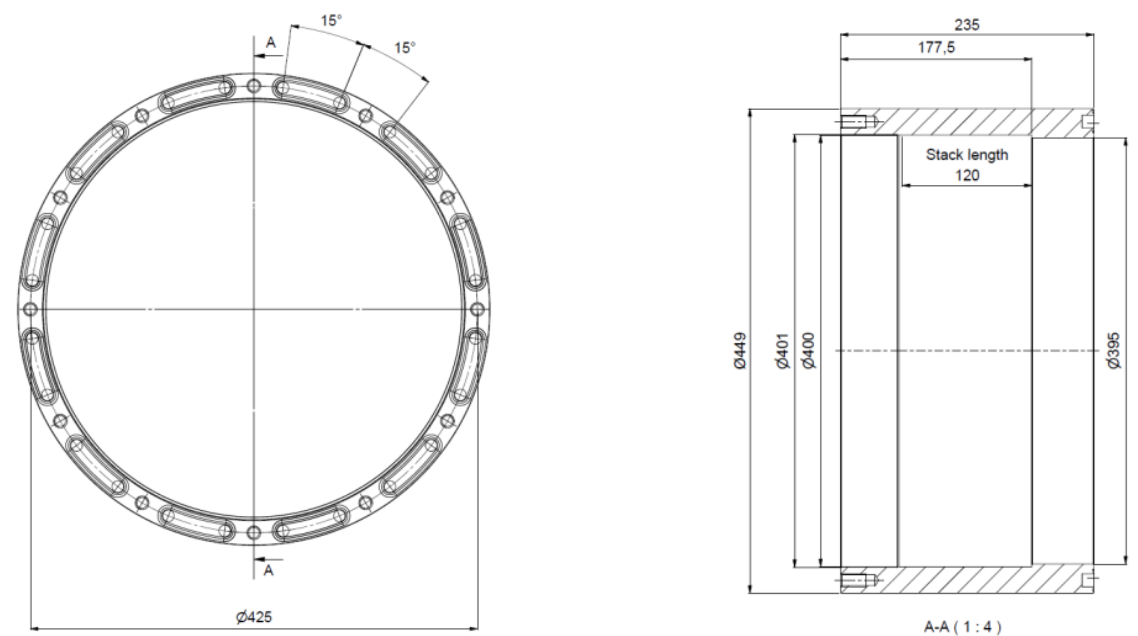

(a)

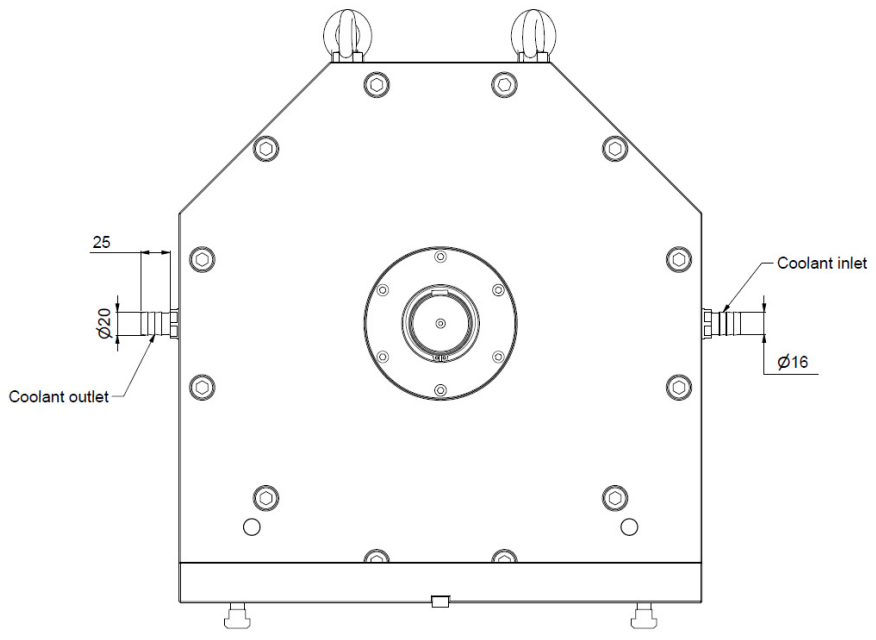

(b)

Figure 22. Water cooling system of the prototype (Courtesy of AE-Group, The Netherlands): (a) technical views of the water jacket; (b) view of the prototype with the water inlet and outlet pipes.

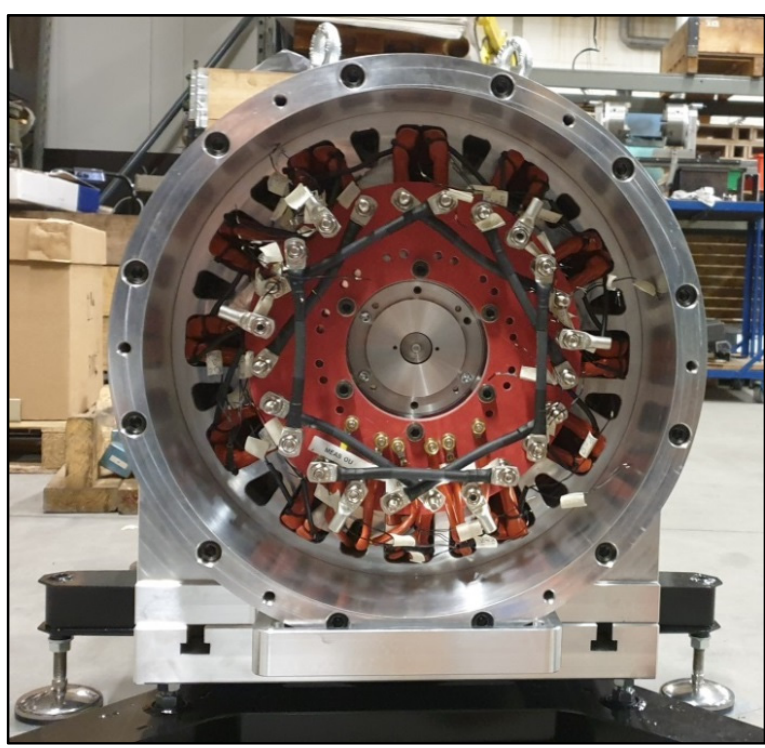

Figure 23. Prototype back side with stator windings and coil connections [29] (Courtesy of AE-Group, The Netherlands). 
Figure 24 shows the prototype installed on its test bench before shipping (Figure 24a) and installed at its final location with a fully operational cooling system (Figure 24b). The cooling system operates in a closed loop like that used in motor vehicles. The radiator allowing heat exchange is clearly visible in Figure $24 \mathrm{~b}$. The installation doesn't include a fan, which can be added to improve the cooling efficiency. The coupling between the two machines is also visible in the fully installed test bench (Figure 24b), while it wasn't present in the test bench before shipping (Figure 24a).

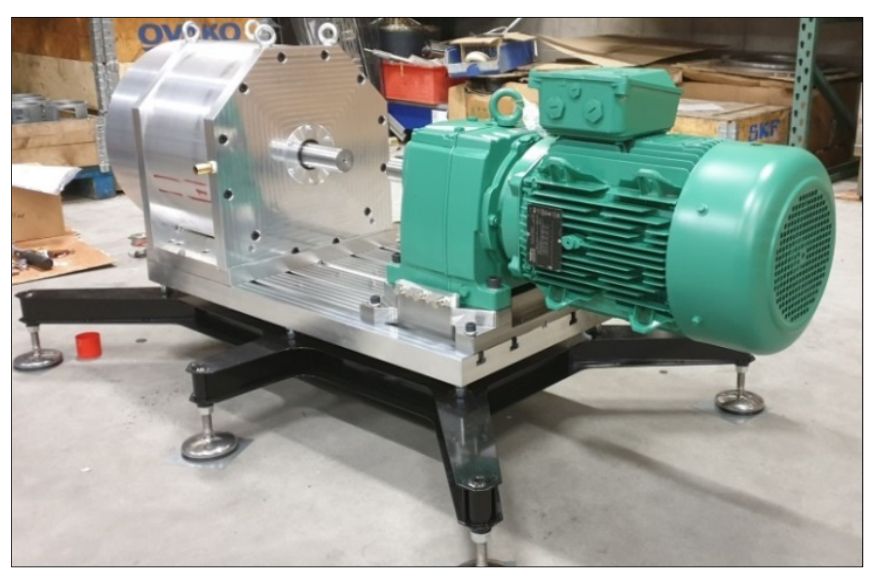

(a)

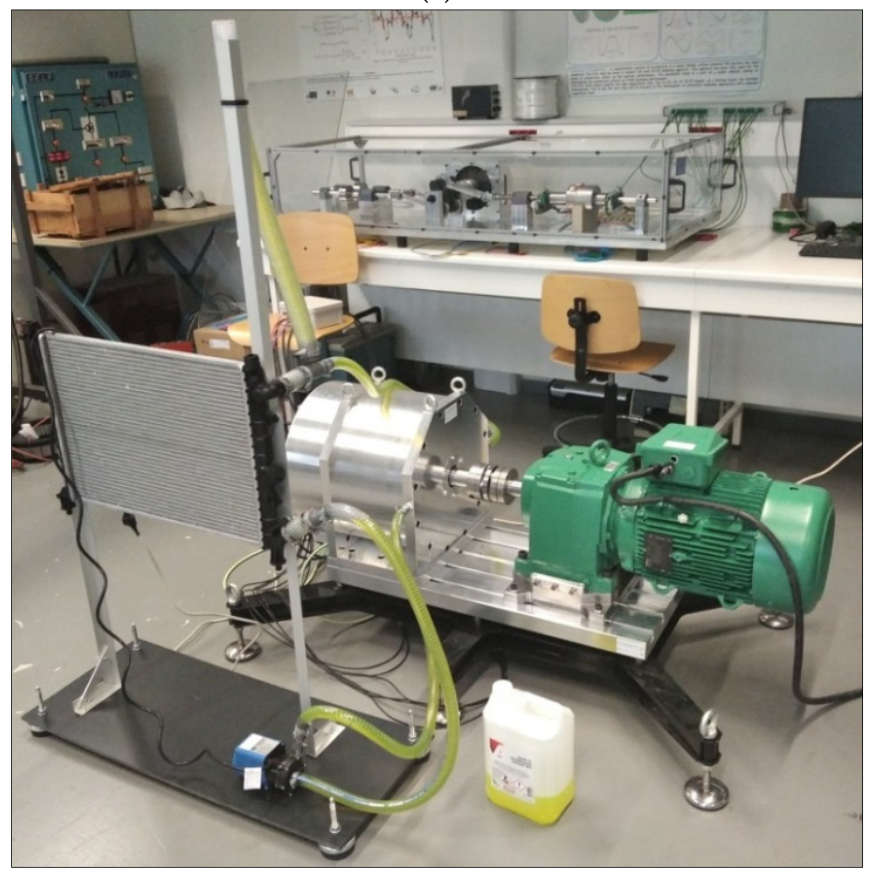

(b)

Figure 24. Prototype on its test bench: (a) test bench before shipping (Courtesy of AE-Group, The Netherlands); (b) fully operational test bench installed at its final location.

\section{Experimental Study}

Table 3 shows the prototype's general characteristics and the measured resistances of the different windings and coils. The acronym DW stands for the damping winding used to reduce the voltage that may be induced in the wound field excitation coils [10-14,29].

The experimental study presented in this research was limited to operations under open-circuit conditions. The air-gap magnetic flux controllability was assessed, and the use of damping windings as a means for mitigating the field windings-induced voltage was confirmed. All measurements were done at a speed of $342 \mathrm{rpm}$. 
Table 3. Constructed prototype's general characteristics.

\begin{tabular}{lclc}
\hline \multicolumn{1}{c}{ Quantity } & Value & \multicolumn{1}{c}{ Quantity } & Value \\
\hline Nominal power $(\mathrm{kW})$ & 10 & Mass of the stator iron core $(\mathrm{kg})$ & 76.5 \\
Nominal speed $(\mathrm{rpm})$ & 300 & Mass of the rotor iron core $(\mathrm{kg})$ & 73.5 \\
External radius $(\mathrm{mm})$ & 200 & Mass of the copper $(\mathrm{Kg})$ & 128 \\
Rotor outer radius $(\mathrm{mm})$ & 120 & Armature windings $(\mathrm{AW})$ number of turns & 9 \\
Active length $(\mathrm{mm})$ & 120 & Excitation coil $(\mathrm{EC})$ number of turns & 31 \\
Air-gap thickness $(\mathrm{mm})$ & 1 & Damping winding $(\mathrm{DW})$ number of turns & 4 \\
Number of rotor teeth & 38 & AW resistance (at room temperature $(\Omega)$ & 0.1 \\
PM type & $\mathrm{NdFeB}$ & EC resistance (at room temperature) $(\Omega)$ & 1.1 \\
Mass of the PM $(\mathrm{kg})$ & 6.5 & DW resistance (at room temperature $(\Omega)$ & 0.25 \\
\hline
\end{tabular}

Flux controllability is very important for the operation of synchronous machines in general, and even more important for hybrid excited synchronous machines specifically [37-44].

Figure 25a shows phase voltage waveforms for three values of the excitation current $\mathrm{I}_{\mathrm{exc}}=-15 \mathrm{~A}, 0 \mathrm{~A}$, and $+15 \mathrm{~A}$. The phase voltage amplitude varied with the excitation current, and, most importantly, the waveforms were close to perfect sinusoidal waveforms, as for waveforms obtained from the finite element computations. Figure $25 \mathrm{~b}$ compares the harmonic content of the three waveforms.

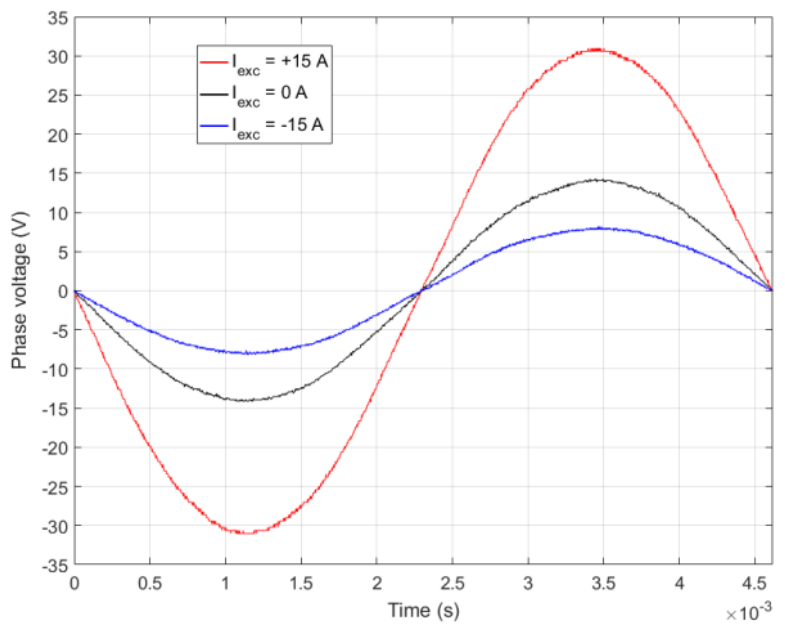

(a)

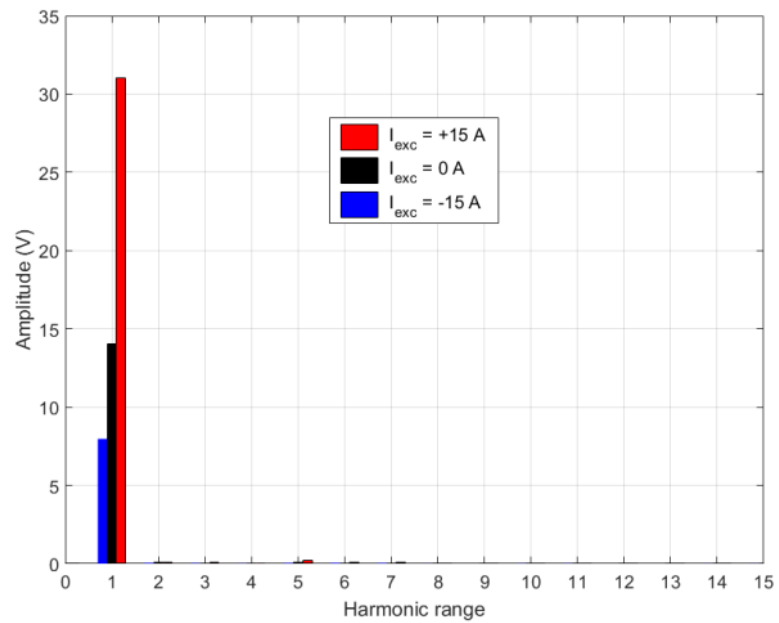

(b)

Figure 25. Measured phase voltage waveforms for $\mathrm{I}_{\mathrm{exc}}=-15 \mathrm{~A}, 0 \mathrm{~A}$, and $+15 \mathrm{~A}$ : (a) waveforms; (b) comparison of harmonic content. 
Figure 26 compares the phase voltage waveform obtained from the finite element computations (FE) and that measured (Meas.) for a null excitation current $\mathrm{I}_{\mathrm{exc}}=0 \mathrm{~A}$. A fairly good agreement was obtained.

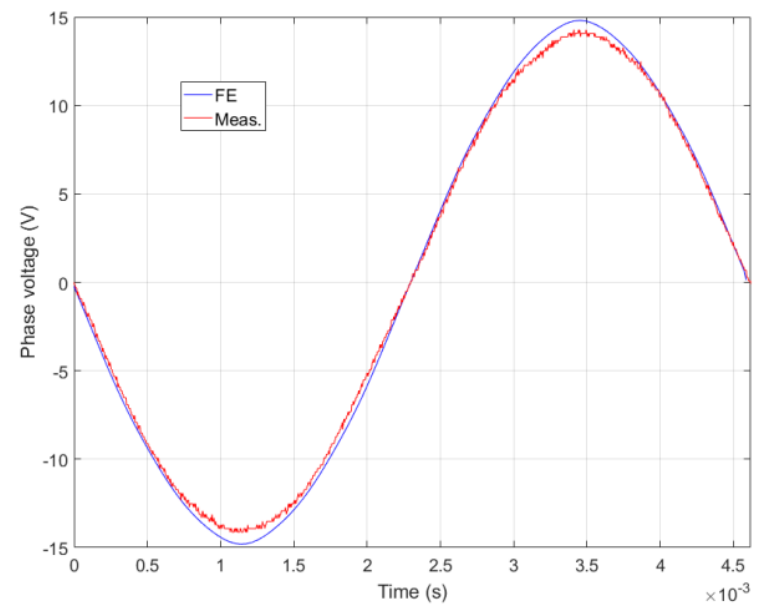

Figure 26. Comparison of FE computed and measured phase voltage waveforms for $\mathrm{I}_{\mathrm{exc}}=0 \mathrm{~A}$.

Figure 27a shows the variation of phase voltage RMS value with the excitation current $\mathrm{I}_{\text {exc. }}$. It can be seen that the magnetic flux control was very effective. The air-gap flux changed with a variation of $+300 \%$, when the air gap flux was enhanced, and $-50 \%$ when it was weakened with respect to the null excitation current $\left(\mathrm{I}_{\mathrm{exc}}=0 \mathrm{~A}\right)$. Figure $27 \mathrm{~b}$ compares the variations of phase voltage RMS values with the excitation current obtained from finite element (FE) computations and experimental measurements (Meas.). Again, a fairly good agreement was achieved.

Compared to results presented in [29], the excitation current values imposed for enhancing the air-gap magnetic flux were pushed further. The installation of the watercooling system reduced the risk of overheating. It should be noticed that for a value of $\mathrm{I}_{\mathrm{exc}}=35 \mathrm{~A}$, the Joule loss of the excitation coils was $1347.5 \mathrm{~W}(>1 \mathrm{~kW})$ if the resistance was constant; this value will increase with the temperature increase.

In order to assess the efficacy of the damper windings for the mitigation of the field windings-induced voltage, a measurement coil was wound exactly the same way as the excitation coils and the damper windings. Figure 28 compares the voltage induced in this measurements coil when the damper windings were open, and when they were short circuited. It can be seen that when short-circuited, the damper windings helped reduce the induced voltage.

Figure 29 shows induced voltage waveforms in the measurement coil for a null excitation current $\left(\mathrm{I}_{\text {exc }}=0\right.$ A) when the damper windings are open and short-circuited. If the reduction of induced voltage using the damper windings is not sufficient, other solutions, such as rotor skewing, could be adopted [11].

It should be noticed that, while the field windings induced voltage was clearly mitigated by short-circuiting of the damper windings, the phase EMF was not affected by the damper windings being open or short-circuited.

This experimental study confirmed expected features observed from finite element computations for operations under open-circuit conditions. The experimental study is still ongoing. A torque meter [36] will be inserted between the two machines in the test bench to perform an experimental study of the machine under load conditions. Thermocouples placed in different locations of the prototype have not been exploited yet. Temperature measurements will help establish a thermal model of the prototype. 


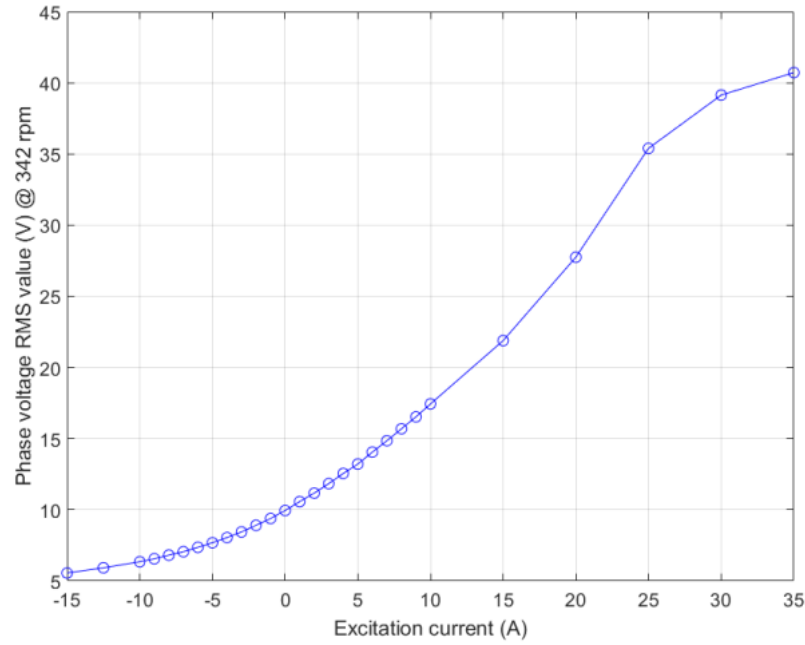

(a)

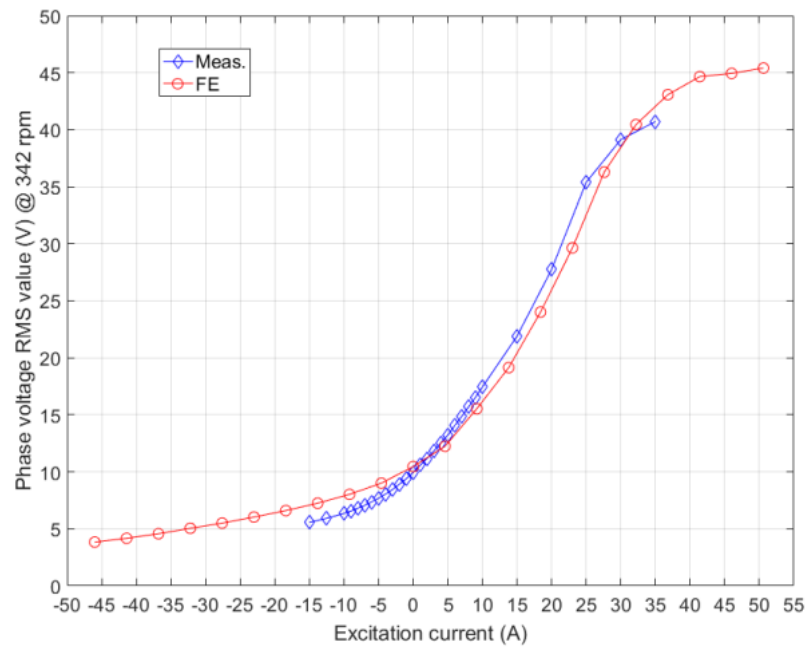

(b)

Figure 27. Phase voltage RMS value variation with excitation current (flux control capability): (a) measured curve; (b) comparison of finite element curve (FE) and measured curve (Meas.).

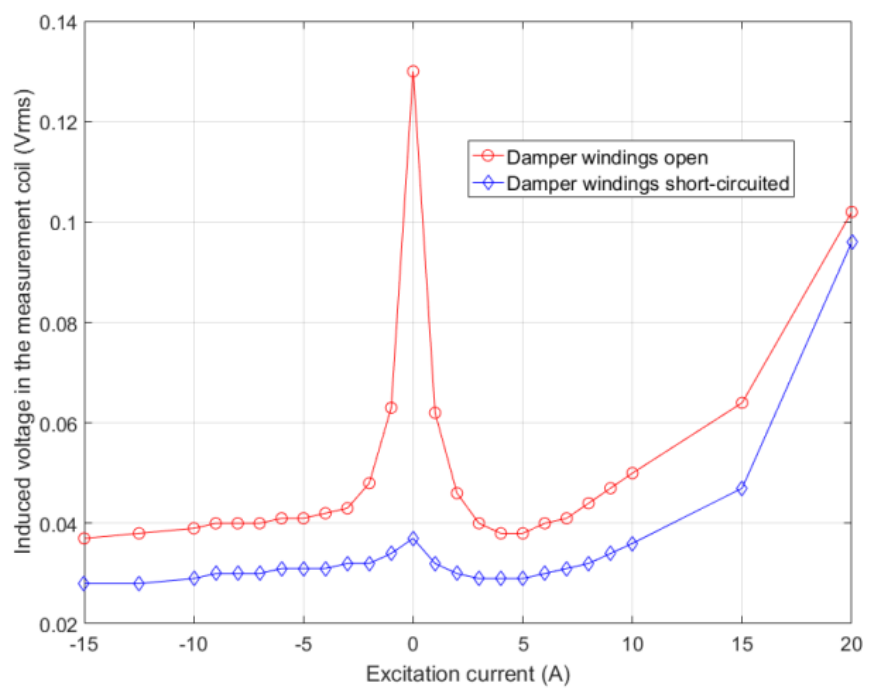

Figure 28. Comparison of induced voltage in the measurement coil for damper windings open and short circuited for different excitation currents. 


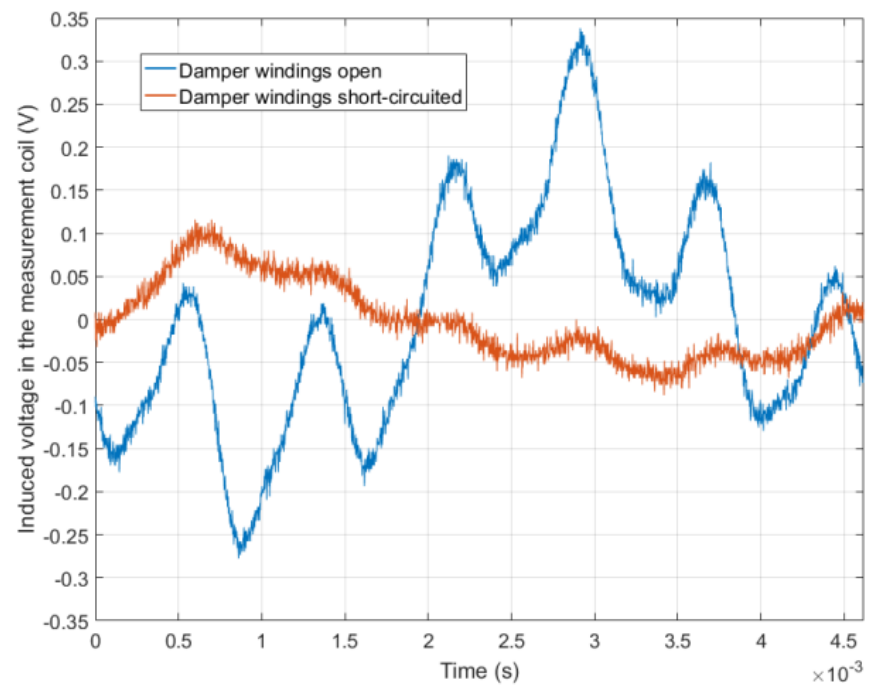

Figure 29. Induced voltage in the measurement coil for $\mathrm{I}_{\mathrm{exc}}=0 \mathrm{~A}$.

\section{Conclusions}

This research involved the design and production of an original generator for marine renewable energy conversion.

The generator combines interesting features, such as the use of hybrid excitation, the flux switching principle and the Vernier effect. A design analysis study confirmed the low power factor which is a characteristic of Vernier machines. However, it was found that hybrid excitation through the magnetic flux control can increase the power factor.

For renewable energy conversion systems, even if power factor improvement is interesting, it should be noticed that the primary energy source is free, and from this point of view performance of the power factor or efficiency is not as important as it could be in the case for applications such as electrical vehicles.

The experimental study of the constructed prototype showed that good flux controllability by the use of hybrid excitation. An adopted solution for the reduction of EC-induced voltage was assessed.

The experimental study is still ongoing; in particular a study under load conditions will be conducted, and the results will be provided in a future paper.

Author Contributions: Writing-review and editing, H.D., Y.A., S.H. and J.J.H.P. All authors have read and agreed to the published version of the manuscript.

Funding: The authors thank the region of Normandy (France) and the European Commission (ERDF), who supported the construction of the prototype under the grant for the NEPTUNE1 project (http:/ / neptune-project.com/en/) (accessed on 22 September 2021).

Data Availability Statement: The data presented in this study are available on request from the corresponding author.

Conflicts of Interest: The authors declare no conflict of interest.

\section{References}

1. ADEME. Vers un Mix Électrique 100\% Renouvelable en 2050; Rapport Final. 2015. Available online: https://librairie. ademe.fr/recherche-et-innovation/2639-a-100-renewable-electricity-mix-analyses-and-optimisations.html (accessed on 22 September 2021).

2. ENEA Consulting. Les Énergies Marines Renouvelables. Enjeux et Solutions Techniques, Mai 2012. Available online: https:// www.enea-consulting.com/static/adc8934d020870e98b7823b4f3e61219/enea-les-energies-marines-renouvelables.pdf (accessed on 22 September 2021).

3. Ministère de la Transition Écologique, Énergies Marines Renouvelables. Available online: https:/ /www.ecologique-solidaire. gouv.fr/energies-marines-renouvelables-0 (accessed on 22 September 2021). 
4. Xie, S.J.; Xu, Z. Multitooth Magnetic Bridge Type Hybrid Excitation Magnetic Flux Switching Motor. Chinese Patent CN101834474 (A), 15 September 2010.

5. Hoang, E.; Lécrivain, M.; Gabsi, M. A new structure of a switching flux synchronous polyphased machine with hybrid excitation. In Proceedings of the 2007 European Conference on Power Electronics and Applications, Aalborg, Denmark, 2-5 September 2007.

6. Sulaimana, E.; Ahmada, M.Z.; Kosakab, T.; Matsui, N. Design optimization studies on high torque and high power density hybrid excitation flux switching motor for HEV. Procedia Eng. 2013, 53, 312-322. [CrossRef]

7. Gaussens, B.; Hoang, E.; Lécrivain, M.; Manfe, P.; Gabsi, M. A Hybrid-excited flux-switching machine for high-speed DCalternator applications. IEEE Trans. Ind. Electron. 2014, 61, 2976-2989. [CrossRef]

8. Zhu, Z.Q.; Chen, J.T.; Pang, Y.; Howe, D.; Iwasaki, S.; Deodhar, R. Analysis of a novel multi-tooth flux-switching PM brushless AC machine for high torque direct-drive applications. IEEE Trans. Magn. 2008, 44, 4313-4316. [CrossRef]

9. Chen, J.T.; Zhu, Z.Q.; Howe, D. Stator and rotor pole Combinations for multi-tooth flux-switching permanent-magnet brushless AC machines. IEEE Trans. Magn. 2008, 44, 4659-4667. [CrossRef]

10. Wu, Z.; Zhu, Z.Q.; Hua, W.; Akehurst, S.; Zhu, X.; Zhang, W.; Hu, J.; Li, H.; Zhu, J. Analysis and suppression of induced voltage pulsation in DC winding of five-phase wound-field switched flux machines. IEEE Trans. Energy Convers. 2019, 34, 1890-1905. [CrossRef]

11. Wu, Z.Z.; Zhu, Z.Q.; Wang, C.; Mipo, J.C.; Personnaz, S.; Farah, P. Reduction of open-circuit DC-winding-induced voltage in wound field switched flux machines by skewing. IEEE Trans. Ind. Electron. 2019, 66, 1715-1726. [CrossRef]

12. Sun, X.; Zhu, Z.Q. Investigation of DC winding induced voltage in hybrid-excited switched-flux permanent magnet machine. IEEE Trans. Ind. Appl. 2020, 56, 3594-3603. [CrossRef]

13. Sun, X.Y.; Zhu, Z.Q.; Wei, F.R. Voltage pulsation induced in DC field winding of different hybrid excitation switched flux machines. In Proceedings of the EEEE Energy Conversion Congress and Exposition (ECCE 2020), Detroit, MI, USA, 11-15 October 2020; pp. 1-8.

14. Sun, X.Y.; Zhu, Z.Q.; Cai, S.; Wang, L.; Wei, F.R.; Shao, B. Influence of stator slot and rotor pole number combination on field winding induced voltage ripple in hybrid excitation switched flux machine. IEEE Trans. Energy Convers. 2021, 36, 1245-1261. [CrossRef]

15. Tiegna, H. Contribution à la Modélisation Analytique des Machines Synchrones à Flux Axial à Aimants Permanents à Attaque Directe en vue de leur Dimensionnement. Application aux Éoliennes. Ph.D. Thesis, Université du Havre, Le Havre, France, 2013.

16. Lee, C.H. Vernier motor and its design. IEEE Trans. Power Appar. Syst. 1963, 82, 343-349. [CrossRef]

17. Rhodes, D.J. Assessment of Vernier motor design using generalised machine concepts. IEEE Trans. Power Appar. Syst. 1977, 96, 1346-1352. [CrossRef]

18. Chau, K.T.; Li, Y.B.; Jiang, J.Z.; Niu, S. Design and control of a PM brushless hybrid generator for wind power application. IEEE Trans. Magn. 2006, 42, 3497-3499. [CrossRef]

19. Liu, C.; Chau, K.T.; Jiang, J.Z.; Jian, L. Design of a new outer-rotor permanent magnet hybrid machine for wind power generation. IEEE Trans. Magn. 2008, 44, 1494-1497.

20. Tiegna, H.; Amara, Y.; Barakat, G.; Dakyo, B. Overview of high power wind turbine generators. In Proceedings of the International Conference on Renewable Energy Research and Applications (ICRERA2012), Nagasaki, Japan, 11-14 November 2012; pp. 1-6.

21. McDonald, A.S. Hybrid Excitation of Synchronous Generators for Wind Turbines. In Proceedings of the 2nd IET Renewable Power Generation Conference (RPG2013), Beihang University (BUAA), Beijing, China, 9-11 September 2013.

22. Amuhaya, L.L.; Kamper, M.J. Design and optimisation of grid compliant variable-flux PM synchronous generator for wind turbine applications. In Proceedings of the IEEE Energy Conversion Congress and Exposition (ECCE 2015), Montreal, QC, Canada, 20-24 September 2015; pp. 1-8.

23. Ployard, M.; Gillon, F.; Ammar, A.; Laloy, D.; Vido, L. Hybrid excitation topologies of synchronous generator for direct drive wind turbine. In Proceedings of the IEEE Energy Conversion Congress and Exposition (ECCE 2016), Milwaukee, WI, USA, 18-22 September 2016; pp. 1-7.

24. Wang, Q.; Niu, S. Overview of flux-controllable machines: Electrically excited machines, hybrid excited machines and memory machines. Renew. Sustain. Energy Rev. 2017, 68, 475-491. [CrossRef]

25. Ching, T.W.; Chau, K.T.; Li, W. Power factor improvement of a linear Vernier permanent-magnet machine using auxiliary DC field excitation. IEEE Trans. Magn. 2016, 52, vg8204804. [CrossRef]

26. Beik, O.; Schofield, N. High-voltage hybrid generator and conversion system for wind turbine applications. IEEE Trans. Ind. Electron. 2018, 65, 3220-3229. [CrossRef]

27. Zhao, X.; Niu, S.; Fu, W. Sensitivity analysis and design optimization of a new hybrid-excited dual-PM generator with relievingDC-saturation structure for stand-alone wind power generation. IEEE Trans. Magn. 2020, 56, 7504105. [CrossRef]

28. Available online: https://greah.univ-lehavre.fr/spip.php?article215 (accessed on 22 September 2021).

29. Hlioui, S.; Gabsi, M.; Ben Ahmed, H.; Barakat, G.; Amara, Y.; Chabour, F.; Paulides, J.J.H. Hybrid excited synchronous machines. IEEE Trans. Magn. 2021. [CrossRef]

30. CEDRAT. User Guide Flux ${ }^{\circledR}$ 11.2. New Features. 2013. Available online: http:/ /www.tianyuantech.com/download/flux112.pdf (accessed on 22 September 2021).

31. Atallah, K.; Howe, D.; Mellor, P.H.; Stone, D.A. Rotor loss in permanent-magnet brushless AC machines. IEEE Trans. Ind. Appl. 2000, 36, 1612-1618. 
32. Frias, A.; Kedous-Lebouc, A.; Chillet, C.; Albert, L.; Calegari, L.; Messal, O. Loss minimization of an electrical vehicle machine considering its control and iron losses. IEEE Trans. Magn. 2016, 52, 8102904. [CrossRef]

33. Ede, J.D.; Atallah, K.; Jewell, G.W.; Wang, J.B.; Howe, D. Effect of axial segmentation of permanent magnets on rotor loss in modular permanent-magnet brushless machines. IEEE Trans. Ind. Appl. 2007, 43, 1207-1213. [CrossRef]

34. Nair, S.S.; Wang, J.; Chin, R.; Chen, L.; Sun, T. Analytical prediction of 3-D magnet eddy current losses in surface mounted PM machines accounting slotting effect. IEEE Trans. Energy Convers. 2017, 32, 414-423. [CrossRef]

35. Leroy-Somer (Nidec). Manuel de l'Électromécanique. Available online: https://www.leroy-somer.com/documentation_pdf/51 81_fr.pdf (accessed on 22 September 2021).

36. HBM. T40B: Mesure de Couple de $50 \mathrm{Nm}$ à 10k Nm. Available online: https:/ / www.hbm.com/fr/3004/t40b-torque-transducerwith-a-rotational-speed-measuring-system/ (accessed on 22 September 2021).

37. Nedjar, B.; Hlioui, S.; Amara, Y.; Vido, L.; Gabsi, M.; Lécrivain, M. A new parallel double excitation synchronous machine. IEEE Trans. Magn. 2011, 47, 2252-2260. [CrossRef]

38. Yamazaki, K.; Nishioka, K.; Shima, K.; Fukami, T.; Shirai, K. Estimation of assist efffects by additional permanent magnets in salient-pole synchronous generators. IEEE Trans. Ind. Electron. 2012, 59, 2515-2523. [CrossRef]

39. Kamiev, K.; Nerg, J.; Pyrhönen, J.; Zaboin, V.; Hrabovcova, V.; Rafajdus, P. Hybrid excitation synchronous generators for island operation. IET Electr. Power Appl. 2012, 6, 1-11. [CrossRef]

40. Kamiev, K.; Pyrhönen, J.; Nerg, J.; Zaboin, V.; Tapia, J. Modeling and testing of an armature-reaction-compensated (PM) synchronous generator. IEEE Trans. Energy Convers. 2013, 28, 849-859. [CrossRef]

41. Kamiev, K. Design and Testing of Armature-Reaction Compensated Permanent Magnet Synchronous Generator for Island Operation. Ph.D. Thesis, Lappeenranta University of Technology, Lappeenranta, Finland, 2013.

42. Kamiev, K.; Nerg, J.; Pyrhönen, J.; Zaboin, V.; Tapia, J. Feasibility of an armature-reaction-compensated permanent-magnet synchronous generator in island operation. IEEE Trans. Ind. Electron. 2014, 61, 5057-5058. [CrossRef]

43. Kamiev, K.; Parviainen, A.; Pyrhönen, J. Hybrid excitation synchronous generators for small hydropower plants. In Proceedings of the 22nd International Conference Electrical Machines (ICEM 2016), Lausanne, Switzerland, 4-7 September 2016.

44. Ammar, A.; Berbecea, A.C.; Gillon, F.; Brochet, P. Influence of the ratio of hybridization on the performances of synchronous generator with hybrid excitation. In Proceedings of the 20th International Conference on Electrical Machines (ICEM 2012), Marseille, France, 2-5 September 2012. 